\title{
Article \\ Synthesis and Characterization of High-Purity Mesoporous Alumina with Excellent Adsorption Capacity for Congo Red
}

\author{
Zhonglin Li ${ }^{1,2,3}$, Ding Wang ${ }^{1,2,3}$, Fengcheng $\mathrm{Lv}^{1,2,3}$, Junxue Chen ${ }^{1,2,3}$, Chengzhi Wu ${ }^{1,2,3}$, Yuping $\mathrm{Li}^{1,2,3}$, \\ Jialong Shen ${ }^{1,2,3}$ and Yibing $\mathrm{Li}^{1,2,3, *}$
}

1 Department of Materials Science and Engineering, Guilin University of Technology, Guilin 541000, China; dahe121133@gmail.com (Z.L.); dingnvhuang@gmail.com (D.W.); lfc13217836260@gmail.com (F.L.); cchenjunxue@gmail.com (J.C.); wuchengzhi73@gmail.com (C.W.); 6613003@glut.edu.cn (Y.L.); Jialong.Shen@glut.edu.cn (J.S.)

2 Collaborative Innovation Center for Exploration of Nonferrous Metal Deposits and Efficient Utilization of Resources, Guilin University of Technology, Guilin 541000, China

3 Key Laboratory of New Processing Technology for Nonferrous Metals and Materials, Ministry of Education, Guilin University of Technology, Guilin 541000, China

* Correspondence: lybgems@glut.edu.cn

\section{check for} updates

Citation: Li, Z.; Wang, D.; Lv, F.; Chen, J.; Wu, C.; Li, Y.; Shen, J.; Li, Y. Synthesis and Characterization of High-Purity Mesoporous Alumina with Excellent Adsorption Capacity for Congo Red. Materials 2022, 15 970. https://doi.org/10.3390/ ma15030970

Academic Editors: Filippo Berto, Abílio M. P. De Jesus and José A. F. O. Correia

Received: 23 December 2021

Accepted: 21 January 2022

Published: 27 January 2022

Publisher's Note: MDPI stays neutral with regard to jurisdictional claims in published maps and institutional affiliations.

Copyright: (C) 2022 by the authors. Licensee MDPI, Basel, Switzerland. This article is an open access article distributed under the terms and conditions of the Creative Commons Attribution (CC BY) license (https:// creativecommons.org/licenses/by/ $4.0 /)$.

\begin{abstract}
We explore a more concise process for the preparation of high-purity alumina and to address the problem of some conventional micro- and nano-adsorbents having difficulty in exposing their adsorption sites to target pollutants in solution due to the heavy aggregation of the adsorbent, which confers poor adsorption properties. The methods of using gamma-phase high-purity mesoporous alumina (HPMA), with its excellent adsorption properties and high adsorption rates of Congo Red, and of using lower-cost industrial aluminum hydroxide by direct aging and ammonium salt substitution were successfully employed. The results showed that the purity of HPMA was as high as $99.9661 \%$ and the total removal rate of impurities was $98.87 \%$, a consequence of achieving a large specific surface area of $312.43 \mathrm{~m}^{2} \mathrm{~g}^{-1}$, a pore volume of $0.55 \mathrm{~cm}^{3} \mathrm{~g}^{-1}$, and an average pore diameter of $3.8 \mathrm{~nm}$. The adsorption process was carried out at $25^{\circ} \mathrm{C}$, the concentration of Congo Red (CR) dye was fixed at $250 \mathrm{mg} \mathrm{L}^{-1}$ and the amount of adsorbent used was $100 \mathrm{mg}$. The HPMA sample exhibited an extremely fast adsorption rate in the first $10 \mathrm{~min}$, with adsorption amounts up to $476.34 \mathrm{mg} \mathrm{g}^{-1}$ and adsorption efficiencies of $96.27 \%$. The adsorption equilibrium was reached in about $60 \mathrm{~min}$, at which time the adsorbed amount was $492.19 \mathrm{mg} \mathrm{g}^{-1}$ and the dye removal rate was as high as $98.44 \%$. One-hundred milligrams of adsorbent were weighed and dispersed in 200-mL CR solutions with mass concentrations ranging from $50-1750 \mathrm{mg} \mathrm{L}^{-1}$ to study the adsorption isotherms. This revealed that the saturation adsorption capacity of the produced HPMA was $1984.64 \mathrm{mg} \mathrm{g}^{-1}$. Furthermore, the process of adsorbing Congo Red in the synthesized product was consistent with a pseudo-second order model and the Langmiur model. It is expected that this method of producing HPMA will provide a productive, easy and efficient means of treating toxic dyes in industrial wastewater.
\end{abstract}

Keywords: HPMA; direct aging method; ammonium salt substitution method; Congo Red adsorption

\section{Introduction}

High-purity alumina (HPA), one of the cutting-edge materials of the 21st century, is widely used in modern industrial products for its excellent physical and chemical properties, for instance, high strength wear and corrosion-resistant candle materials, special gas additives, advanced ceramic materials, catalysts and their carriers, biomedical, protective materials, single crystal materials, laser crystals and many other fields [1-11]. Impurity elements are mostly present in alumina in the form of oxides, such as sodium oxide, iron oxide, silicon dioxide, etc., and diverse miscellaneous impurities have different effects on its performance, thus limiting the widespread use of alumina. HPA is classified into the $3 \mathrm{~N}(99.9 \%), 4 \mathrm{~N}(99.99 \%)$ and $5 \mathrm{~N}(99.999 \%)$ grades, according to the mass purity of the 
alumina. HPA price and volume demand both depend on its purity [12], as shown in Table 1 . Therefore, the study of the preparation process of high-purity alumina has very broad prospects, far-reaching significance and economic impact.

Table 1. Approximate market price for HPA by product purity. Ranges are estimated from various sources.

\begin{tabular}{cccc}
\hline HPA Purity (by Weight) & 3N (99.9\%) & $4 \mathrm{~N}(\mathbf{9 9 . 9 9 \% )}$ & $5 \mathrm{~N} \mathrm{(99.999 \% )}$ \\
\hline $\begin{array}{c}\text { approx. market price } \\
\text { range (US\$/tonne) }\end{array}$ & $\$ 5000-\$ 15,000$ & $\$ 15,000-\$ 30,000$ & $\$ 30,000-\$ 50,000$ \\
\hline
\end{tabular}

With the progress in and development of science and technology, there have been a series of preparation methods for HPA materials, including organic aluminum alcohol hydrolysis, ammonium aluminum sulfate pyrolysis, ammonium aluminum carbonate pyrolysis, the modified Bayer method and the roasting method, etc. [13-20].

The method of alcohol-aluminum hydrolysis has often been employed in China. In detail, in the presence of a catalyst, metallic aluminum and organic alcohol are mixed and reacted to obtain an alcohol-aluminum solution, which is followed by hydrolysis and high-temperature roasting of the intermediates to synthesize HPA products. The advantage of this method is the high purity and small particle size of the prepared alumina products, whereas, its high production cost and its being a complicated and uncontrollable process limit its economic efficiency.

The pyrolysis of ammonium aluminum sulfate is a traditional preparation method that has been studied by researchers both in China and globally that focuses on controlling the synthesis conditions to obtain pure ammonium aluminum sulfate, or on crystallizing the resulting ammonium aluminum sulfate several times for purification purposes. The process is cheap and is easily obtains the required raw materials, while the parent alcohol can be recycled, reducing the burden of waste liquid disposal. However, the product may not be calcined sufficiently, resulting in significant sulfate content and unsatisfactory purity, and the ammonia and sulfur trioxide produced pollute the environment, which is not conducive to the realization of environmental friendliness.

The ammonium aluminum carbonate pyrolysis method improves the above technology of the pyrolysis of ammonium aluminum sulfate and overcomes the disadvantages of the production process of ammonium aluminum sulfate, which pollute the environment; however, this method increases the burden of $\left(\mathrm{NH}_{4}\right) \mathrm{SO}_{4}$ waste liquid disposal, which is also pollutes the environment.

Congo Red (CR), a water-soluble acidic anionic azo pigment, is commonly used in the textile industry because of its strong adsorption to cellulose; thus, the discharge of wastewater in the textile industry contains Congo Red components. It can affect aquatic organisms and the food chain, even if the CR concentration in water is very low [21], such as by increasing chemical oxygen demand (COD) at the water surface and interfering with sunlight penetration through the water surface, reducing photosynthetic activity [22]. In addition, it can seriously affect kidney function, the reproductive system, liver function, the brain and central nervous system and eventually cause allergic reactions [23] to water quality or even cancer. Given China's emphasis on environmental protection and the gradual increase in national awareness of environmental protection, a large number of technical means of eliminating the impact of pigments on people's lives and the environment have been widely studied-for instance, turbidity point extraction [24-27], precipitation [28-32], membrane filtration [33,34], adsorption [35-38] and photocatalytic degradation [39-42]. Among them, adsorption has become the main treatment method for textile industry wastewater, with many advantages, such as low material price, little required equipment, a simple treatment process and superior treatment effects; thus, it is widely used. The key to this technology is the choice of adsorbent, such as activated carbon, which is of interest because it requires only a simple design, is easy to handle, and is sensitive to toxic substances, but its high 
cost has prevented its widespread use as an adsorbent in developing countries. Thus, low-cost natural materials, industrial wastes, and agricultural by-products have attracted the interest of researchers as alternatives to those high-cost adsorbents, such as rubber peels [43], sawdust [44], rice husks [45], and lignocellulose [46]. High purity mesoporous alumina (HPMA) with its large specific surface, suitable pore structure, excellent physical properties, chemical stability and activity has been extensively employed in the area of Congo Red adsorption. In combination with the structural characteristics of HPMA itself, the following aspects are considered to improve its adsorption performance: increasing the specific surface area of HPMA [23]; controlling the structural properties of alumina texture, i.e., the pore structure of alumina $[47,48]$; spherification of alumina powder morphology to improve its water permeability [49]; and the use of composites of other functional active materials to improve its adsorption activity [50,51]. The focus of this study is the synthesis of HPMA with excellent adsorption properties and high adsorption rates of Congo Red using lower-cost industrial aluminum hydroxide by direct ageing and the ammonium salt substitution method to increase the pore structure and specific surface area of the material, thus enhancing the surface energy and surface bonding energy, which can be easily stabilized by bonding with other atoms and enhance the chemical activity of HPMA. The greater chemical activity induces corresponding changes in atomic transport and conformation on the surface of the alumina nanoparticles, leading to changes in the electron spin conformation and electronic energy spectrum on the surface of the HPMA material particles, which contributes to the improved adsorption performance of HPMA. Moreover, the influence on purity, crystalline structure, porosity, morphology and the Congo Red dye adsorption properties of certain key preparation parameters are also investigated.

\section{Experimental Procedures}

\subsection{Materials}

Industrial $\mathrm{Al}(\mathrm{OH})_{3}$ was offered by an aluminum company in Guangxi, China, the main composition of which is shown in Table 2 . The other analytically pure reagents used, hydrochloric acid, ammonium oxalate, ammonium acetate and ammonium carbonate, were all purchased from Xi-long Chemical Co., Shantou, China, and were used without any pretreatment.

Table 2. Components of industrial aluminum hydroxide.

\begin{tabular}{cccc}
\hline \multicolumn{5}{c}{ Component Content $\left(w_{\mathrm{B}} / \%\right)$} \\
\hline $\mathrm{SiO}_{2}$ & $\mathrm{Fe}_{2} \mathrm{O}_{3}$ & $\mathrm{Na}_{\mathbf{2}} \mathrm{O}$ & $\mathrm{Al}(\mathrm{OH})_{3}$ \\
\hline 1.25 & 1.16 & 0.58 & 97.01 \\
\hline
\end{tabular}

\subsection{Preparation of Mesoporous Alumina Materials}

A mass of $219.4 \mathrm{~g}$ of $\mathrm{NaOH}$ was dissolved in $500 \mathrm{~mL}$ of ultra-pure water to obtain a highly-concentrated sodium hydroxide solution, $281.4 \mathrm{~g}$ of industrial $\mathrm{Al}(\mathrm{OH})_{3}$ was slowly added into the $\mathrm{NaOH}$ solution with magnetic stirring under hydrothermal conditions at $95{ }^{\circ} \mathrm{C}$ until all solids dissolved, and then it was filtered and diluted to obtain a range of sodium aluminate solutions with diverse initial concentrations of $30 \mathrm{~g} \mathrm{~L}^{-1}, 60 \mathrm{~g} \mathrm{~L}^{-1}$, $90 \mathrm{~g} \mathrm{~L}^{-1}$ and $120 \mathrm{~g} \mathrm{~L}^{-1}$. The $\mathrm{pH}$ value of the $\mathrm{NaAl}(\mathrm{OH})_{4}$ solution was adjusted to 10 by slowly dropping in a dilute hydrochloric acid solution. The $\mathrm{NaAl}(\mathrm{OH})_{4}$ solution was aged at appropriate temperature $\left(30^{\circ} \mathrm{C}, 60{ }^{\circ} \mathrm{C}, 90^{\circ} \mathrm{C}\right.$ and $\left.120^{\circ} \mathrm{C}\right)$ for a period of time $(1 \mathrm{~h}, 1.5 \mathrm{~h}, 2 \mathrm{~h}, 2.5 \mathrm{~h}, 3 \mathrm{~h}, 3.5 \mathrm{~h}$ and $4 \mathrm{~h}$ ), and washed to neutral after centrifugation. The ammonium-rich $\gamma-\mathrm{AlO}(\mathrm{OH})$ was obtained by adding excess ammonium solution $\left(\left(\mathrm{NH}_{4}\right)_{2} \mathrm{CO}_{3}, \mathrm{CH}_{3} \mathrm{COONH}_{4}\right.$ and $\left.\left(\mathrm{NH}_{4}\right)_{2} \mathrm{C}_{2} \mathrm{O}_{4}\right)$ for ammonium substitution reaction. The colloidal product was dried in a blast-drying oven at $150{ }^{\circ} \mathrm{C}$ for more than $2 \mathrm{~h}$, and then roasted under a constant temperature $\left(500{ }^{\circ} \mathrm{C}, 700{ }^{\circ} \mathrm{C}, 900{ }^{\circ} \mathrm{C}\right.$ and $\left.1100{ }^{\circ} \mathrm{C}\right)$ for $4 \mathrm{~h}$ with temperature rising at a rate of $10{ }^{\circ} \mathrm{C} \mathrm{min}^{-1}$ to obtain the product, high purity mesoporous $\gamma-\mathrm{Al}_{2} \mathrm{O}_{3}$ 


\subsection{Characterization of Alumina Materials}

The impurity content of alumina (iron, alumina, and silicon) was measured by X-ray fluorescence spectrum analysis (XRF, XRF-1800, Shimadzu Japan Ltd., Shanghai, China) to obtain the individual impurities removal rates from alumina products, and was calculated with the following formula:

$$
R=\left(M_{0}-M_{t}\right) / M_{0}
$$

$\mathrm{M}_{0}$ : the individual impurities mass ratio of industrial $\mathrm{Al}(\mathrm{OH})_{3}$ shown in Table 1. $M_{t}$ : the individual impurity's mass ratio of alumina product. $R$ : the individual impurity's removal rate.

The morphology of the material was studied using a scanning electron microscope (SEM, S-4800, Hitachi Works, Ltd., Tokyo, Japan) worked at $5.0 \mathrm{KV}$ and transmission electron microscopy (TEM, JEM-2100F, JEOL, Beijing, China). Structural phase analysis was carried out by $\mathrm{X}$-ray diffraction (XRD) using $\mathrm{CuK} \alpha$ radiation. The equipment was $X^{\prime}$ Pert PRO (PANalytical B.V., Almelo, The Netherlands), and the continuous mode was used to collect $2 \theta$ data from $10^{\circ}$ to $80^{\circ}$ with an $8^{\circ} \mathrm{min}^{-1}$ sampling pitch. The thermal stability of the adsorbent was determined using a Q500 thermogravimetric analyzer from TA company. The temperature range was $35-800{ }^{\circ} \mathrm{C}$ with a nitrogen $\left(\mathrm{N}_{2}\right)$ atmosphere and the rate of increase was $10{ }^{\circ} \mathrm{C} \mathrm{min}^{-1}$. The specific surface area, pore volume and pore size distribution of the sorbent were determined by liquid nitrogen adsorption using the surface area and pore porosimetry analyzer NoVA 1200e (Quantachrome Instruments, Shanghai, China) calculated using the Brunauer-Emmett-Teller (BET) and Barret-Joyner-Hallender $(\mathrm{BJH})$ methods, respectively. The zeta $(\zeta)$ potential of the adsorbents was measured using a nanoparticle size and zeta point analyzer (Nani-ZS, Malvern, UK) at a pH value of 7.

\subsection{Adsorption Experiments on HPMA Materials}

The adsorption property of HPMA powder and its kinetic study were conducted. Twohundred milliliters of Congo Red aqueous solution (mass concentration of $250 \mathrm{mg} \mathrm{L}^{-1}$ ) was added in a conical flask, adjusted to the $\mathrm{pH}$ value of 4 through $0.1 \mathrm{M}$ hydrochloric acid and $100 \mathrm{mg}$ of the as-prepared HPMA material. The conical flask was then placed in a thermostatic water bath (DF-101S, Gongyi, China) with a controlled stirring speed of $145 \mathrm{rpm}$ and a temperature of $25^{\circ} \mathrm{C}$. The solution was removed at pre-determined time intervals and the concentration of Congo Red in the removed solution was measured using Shimadzu UV-9000S spectrophotometer. The solution was then returned. The amount of sorption $q_{t}$ at different times was calculated using the following equation.

$$
q_{t}=\left(C_{0}-C_{t}\right) V / m
$$

$\mathrm{C}_{0}$ : the initial concentration of Congo Red $\left(\mathrm{mg} \mathrm{L}^{-1}\right)$

$C_{t}$ : the mass content of Congo Red for the corresponding time $\left(\mathrm{mg} \mathrm{L}^{-1}\right)$

$V$ : the volume of solution (L)

$m$ : mass of HPMA materials (g)

$q_{t}:$ mass of adsorbent adsorbed per unit mass of adsorbent at time $t$

To study the adsorption isotherms, $100 \mathrm{mg}$ of adsorbent was weighed and dispersed in 200-mL CR solutions with mass concentrations of $50-1750 \mathrm{mg} \mathrm{L}^{-1}$. These solutions were stirred for $24 \mathrm{~h}$ until adsorption equilibrium, and $4 \mathrm{~mL}$ of the supernatant after centrifugation was analyzed by UV-Vis spectrometer (UV-9000S, Shimadzu, Shanghai, China). The maximum adsorbed mass $q_{\mathrm{m}}$ for $\mathrm{CR}$ after equilibrium was calculated by the following equation.

$$
q_{m}=\left(C_{0}-C_{e}\right) V / m
$$

$\mathrm{C}_{0}$ : the initial concentration of Congo Red $\left(\mathrm{mg} \mathrm{L}^{-1}\right)$

$C_{e}$ : the mass content of Congo Red at adsorption equilibrium $\left(\mathrm{mg} \mathrm{L}^{-1}\right)$

$V$ : the volume of solution (L)

$m$ : mass of HPMA materials (g) 
$q_{m}:$ the maximum adsorbed mass

\section{Results and Discussion}

\subsection{Effects of Various Factors on the Mesoporous Alumina Product}

\subsubsection{Initial Concentration of $\mathrm{NaAl}(\mathrm{OH})_{4}$ Solution}

The initial concentration of $\mathrm{NaAl}(\mathrm{OH})_{4}$ solution is a key parameter to the preparation of high-purity MA material. Therefore, a series of alumina materials were prepared with the ageing temperature of $60{ }^{\circ} \mathrm{C}$, ageing time of $2 \mathrm{~h}$, and the roasting temperature of $500{ }^{\circ} \mathrm{C}$. The mass concentration of the $\left(\mathrm{NH}_{4}\right)_{2} \mathrm{CO}_{3}$ solution was $75 \mathrm{~g} \mathrm{~L}^{-1}$ and for the $\mathrm{NaAl}(\mathrm{OH})_{4}$ solutions, with different mass concentrations, were $30 \mathrm{~g} \mathrm{~L}^{-1}, 60 \mathrm{~g} \mathrm{~L}^{-1}, 90 \mathrm{~g} \mathrm{~L}^{-1}$ and $120 \mathrm{~g} \mathrm{~L}^{-1}$. The solutions were prepared to study the effect of the initial mass concentration on the impurities contents of the products. As shown in Figure 1 and Table 3, with the increase of the initial concentration of $\mathrm{NaAl}(\mathrm{OH})_{4}$ from $30 \mathrm{~g} \mathrm{~L}^{-1}$ to $120 \mathrm{~g} \mathrm{~L}^{-1}$, the iron oxide content gradually increased from $0.0048 \%$ to $0.009 \%$, the silica content initially decreased from $0.0098 \%$ to $0.0054 \%$ and then increased to $0.0083 \%$; the sodium oxide content similarly firstly decreased from $0.046 \%$ to $0.022 \%$ and then increased to $0.038 \%$. The overall impurity removal rate, on the other hand, increased from $97.97 \%$ to $98.86 \%$ and then decreased to $98.15 \%$ and the purity of alumina rises from $99.9393 \%$ to $99.9661 \%$ and then falls to $99.9447 \%$.

$$
\begin{gathered}
\mathrm{Al}(\mathrm{OH})_{3}+\mathrm{NaOH}=\mathrm{NaAl}(\mathrm{OH})_{4} ; \\
\mathrm{Fe}_{2} \mathrm{O}_{3}+2 \mathrm{NaOH}+3 \mathrm{H}_{2} \mathrm{O}=2 \mathrm{NaFe}(\mathrm{OH})_{4} ; \\
\mathrm{SiO}_{2}+2 \mathrm{NaOH}=\mathrm{Na}_{2} \mathrm{SiO}_{3}+\mathrm{H}_{2} \mathrm{O} ; \\
2 \mathrm{NaAl}(\mathrm{OH})_{4}+1.7 \mathrm{Na}_{2} \mathrm{SiO}_{3}=\mathrm{Na}_{2} \mathrm{O} \mathrm{Al}{ }_{2} \mathrm{O}_{3} \cdot 1.7 \mathrm{SiO}_{2} \cdot n \mathrm{H}_{2} \mathrm{O} \downarrow+3.4 \mathrm{NaOH}+3 \mathrm{H}_{2} \mathrm{O}
\end{gathered}
$$

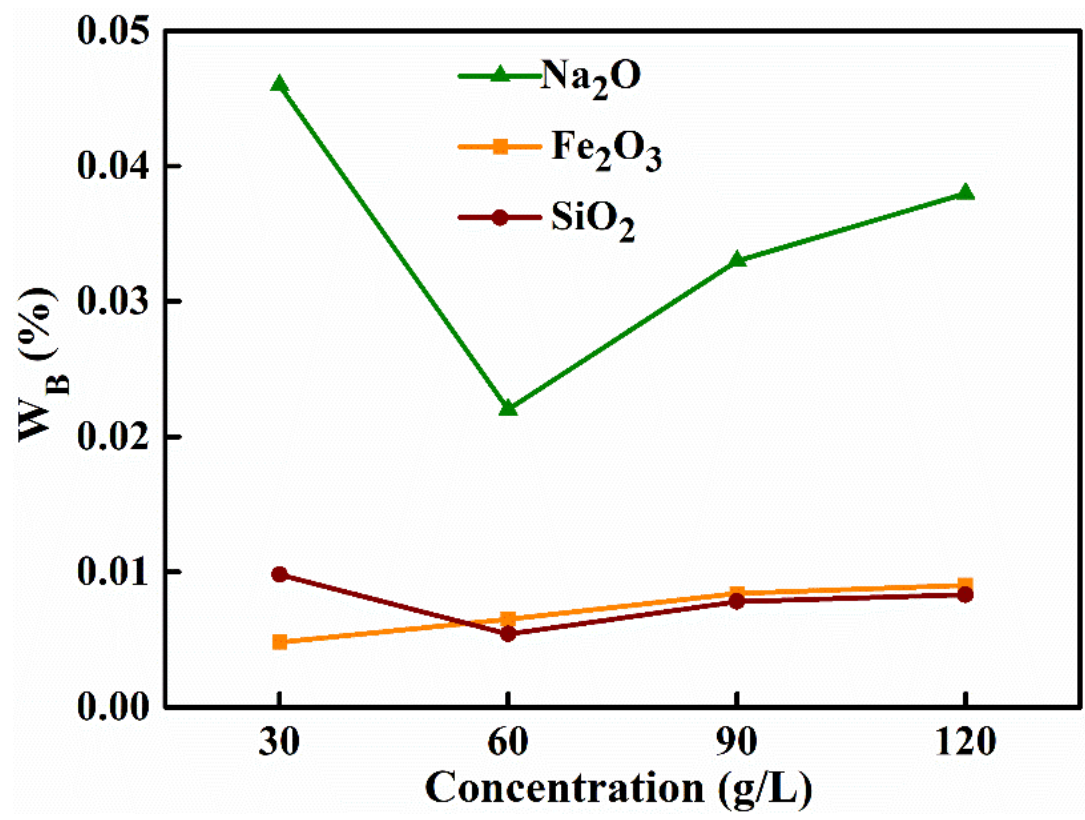

Figure 1. Effect of initial concentration of $\mathrm{NaAl}(\mathrm{OH})_{4}$ solution on the mass ratio of MA. 
Table 3. Influence of initial $\mathrm{NaAl}(\mathrm{OH})_{4}$ solution concentration on impurity removal efficiency and alumina purity.

\begin{tabular}{cccccc}
\hline \multirow{2}{*}{$\begin{array}{c}\text { Concentration } \\
\left(\mathbf{g ~ L ~ L ~}^{-1}\right)\end{array}$} & $\mathbf{F e}_{\mathbf{2}} \mathbf{O}_{\mathbf{3}}$ & $\mathbf{S i O}_{\mathbf{2}}$ & $\mathbf{N a} \mathbf{~} \mathbf{O}$ & $\begin{array}{c}\text { Total Removal } \\
\text { Rate }\end{array}$ & $\begin{array}{c}\text { Alumina Purity } \\
(\%)\end{array}$ \\
\cline { 2 - 5 } & 99.58 & 99.21 & 92.06 & 97.97 & 99.9393 \\
60 & 99.44 & 99.57 & 96.21 & 98.86 & 99.9661 \\
90 & 99.28 & 99.37 & 94.31 & 98.36 & 99.9509 \\
120 & 99.22 & 99.33 & 93.45 & 98.15 & 99.9447 \\
\hline
\end{tabular}

From the above reaction equation, it can be seen that the $\mathrm{SiO}_{2}$ impurities present in the raw material reacted with $\mathrm{NaOH}$ to form $\mathrm{NaSiO}_{3}$, and $\mathrm{NaSiO}_{3}$ further reacted with $\mathrm{NaAl}(\mathrm{OH})_{4}$ to form precipitates, which facilitated the removal of $\mathrm{SiO}_{2}$. On the other hand, iron oxide reacted with sodium aluminate to form soluble $\mathrm{NaFe}(\mathrm{OH})_{4}$, which increased the amount of iron oxide impurities in the MA. Meanwhile, as the initial concentration gradually increased, the concentration of sodium ions rose and the viscosity of the solution increased, so that the content of each impurity in the product showed an increasing trend after the concentration exceeded $60 \mathrm{~g} \mathrm{~L}^{-1}$.

\subsubsection{Aging Temperature}

As with other process parameters, aging temperature had a definite effect on the purity of the final product. A series of alumina materials were prepared with a $\mathrm{NaAl}(\mathrm{OH})_{4}$ solution concentration of $60 \mathrm{~g} \mathrm{~L}^{-1}$, an ageing time of $2 \mathrm{~h}$, the roasting temperature of $500^{\circ} \mathrm{C}$, the mass concentration of the $\left(\mathrm{NH}_{4}\right)_{2} \mathrm{CO}_{3}$ solution of $75 \mathrm{~g} \mathrm{~L}^{-1}$ and the ageing temperatures $30{ }^{\circ} \mathrm{C}, 60^{\circ} \mathrm{C}, 90^{\circ} \mathrm{C}$ and $120^{\circ} \mathrm{C}$. The results of the effect of different aging temperature on the impurity content in the product alumina are shown in Table 4 and Figure 2. It can be seen that with the increase of aging temperature from $30{ }^{\circ} \mathrm{C}$ to $60^{\circ} \mathrm{C}$, there was no significant change in the mass fractions of iron oxide or silica, while the content of sodium oxide decreased significantly (from $0.04 \%$ to $0.022 \%$ ). When the temperature exceeded $60{ }^{\circ} \mathrm{C}$, the mass ratio of all impurities increased, from $0.0065 \%$ to $0.0081 \%$ for $\mathrm{Fe}_{2} \mathrm{O}_{3}$, from $0.0054 \%$ to $0.0067 \%$ for silica, and to $0.030 \%$ for $\mathrm{Na}_{2} \mathrm{O}$. The total removal of impurities was first increased, from $98.26 \%$ to $98.86 \%$, and then decreased to $98.53 \%$, and the purity of alumina rose from $99.9481 \%$ to $99.9661 \%$ and then fell to $99.9552 \%$. Excessive increases in ageing temperature, therefore, not only result in a loss of energy but also reduce the purity of the alumina. The reason for this change is that when the temperature was too low (less than $60^{\circ} \mathrm{C}$ ), the viscosity of the slurry was too large for the removal of impurities and the final precipitation produced resulted in an increase in the amount of sodium impurities contained in the material. When the temperature was raised to $60^{\circ} \mathrm{C}$, the solution had a more suitable viscosity, there were more nuclei, the $\mathrm{Al}(\mathrm{OH})_{3}$ particles formed were smaller, the crystals had less effect on the impurities, and fewer impurities remained and were adsorbed. However, as the temperature gradually rose, the crystals formed were too large, the force between the crystals was enhanced, the viscosity of the solution was greater at this time, and the adhesion effect on the impurities was greater. So, after the temperature exceeds $60^{\circ} \mathrm{C}$, the content of all the impurities increased, and the effect of impurity removal gradually became worse. 
Table 4. Influence of aging temperature on impurity removal efficiency and alumina purity.

\begin{tabular}{cccccc}
\hline \multirow{2}{*}{$\begin{array}{c}\text { Aging } \\
\text { Temperature }\end{array}$} & \multicolumn{4}{c}{ Removal Efficiency (\%) } & Alumina Purity \\
\cline { 2 - 5 }$\left({ }^{\circ} \mathbf{C}\right)$ & $\mathbf{F e}_{2} \mathbf{O}_{3}$ & $\mathbf{S i O}_{2}$ & $\mathbf{N a}_{\mathbf{2}} \mathbf{O}$ & $\begin{array}{c}\text { Total Removal } \\
\text { Rate }\end{array}$ & \\
\hline 30 & 99.45 & 99.56 & 93.10 & 98.26 & 99.9481 \\
60 & 99.44 & 99.57 & 96.21 & 98.86 & 99.9661 \\
90 & 99.32 & 99.48 & 95.17 & 98.58 & 99.9576 \\
120 & 99.30 & 99.52 & 94.83 & 98.53 & 99.9552 \\
\hline
\end{tabular}

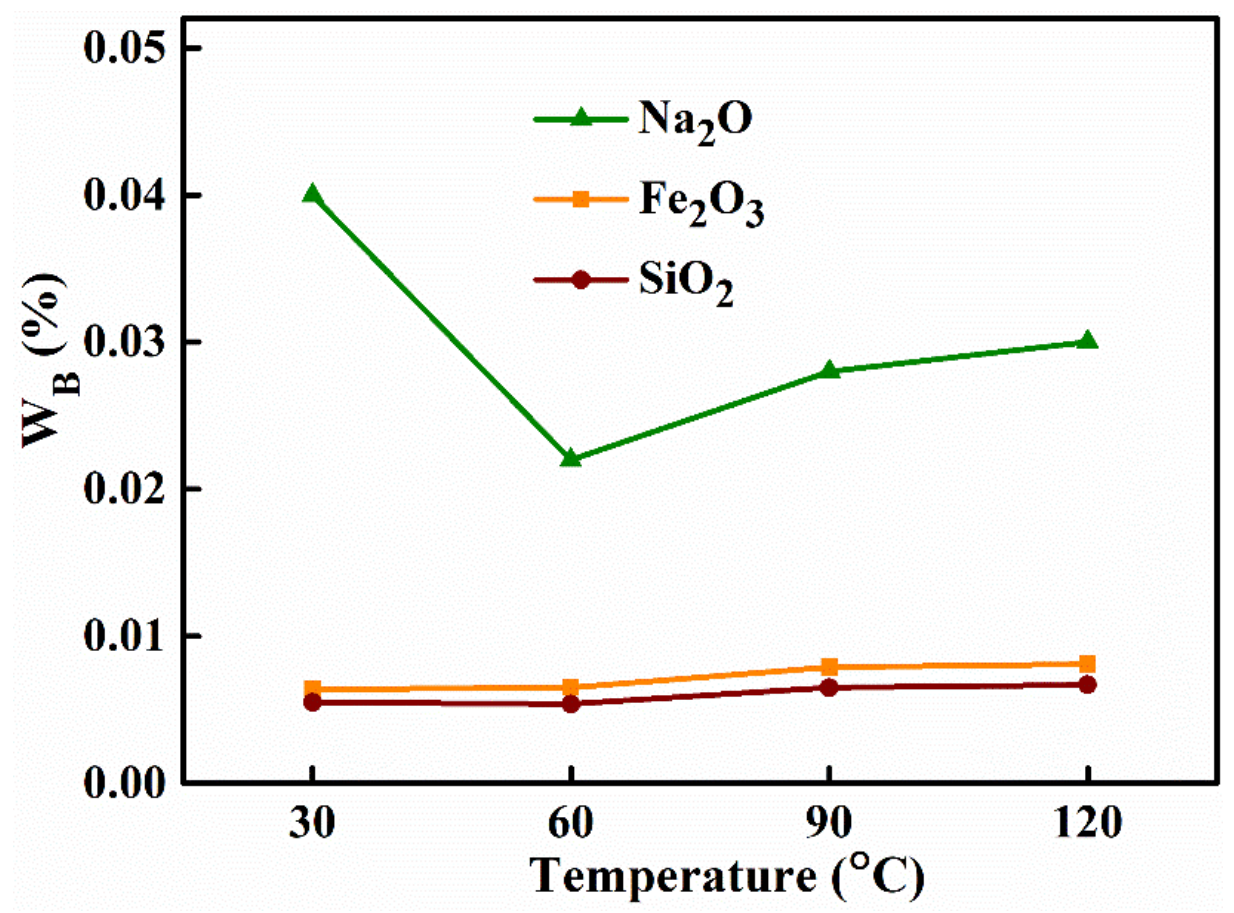

Figure 2. Effect of aging temperature on the impurity mass ratio in the product alumina.

\subsubsection{Aging Time}

Ageing time is also an important parameter in the synthesis and preparation process, so a careful study of ageing time is of general importance. A collection of alumina materials were synthesized with a $\mathrm{NaAl}(\mathrm{OH})_{4}$ solution concentration of $60 \mathrm{~g} \mathrm{~L}^{-1}$, ageing temperature of $60{ }^{\circ} \mathrm{C}$, roasting temperature of $500{ }^{\circ} \mathrm{C}$, a mass concentration of the $\left(\mathrm{NH}_{4}\right)_{2} \mathrm{CO}_{3}$ solution of $75 \mathrm{~g} \mathrm{~L}^{-1}$ and the ageing times $1 \mathrm{~h}, 1.5 \mathrm{~h}, 2 \mathrm{~h}, 2.5 \mathrm{~h}, 3 \mathrm{~h}, 3.5 \mathrm{~h}, 4 \mathrm{~h}$. The effects of ageing time on the purity and impurity removal rate of the material are shown in Figure 3 and Table 5, respectively. When the time was extended from $1 \mathrm{~h}$ to $2 \mathrm{~h}$, there was no significant change in the content of iron oxide and silica, while the content of sodium oxide decreased significantly (from $0.038 \%$ to $0.022 \%$ ). When the time exceeded $2 \mathrm{~h}(2.5-4.0 \mathrm{~h}$ ), the content of all impurities increased, from $0.0065 \%$ to $0.0079 \%$ for $\mathrm{Fe}_{2} \mathrm{O}_{3}$, from $0.0054 \%$ to $0.0071 \%$, for silica and to $0.048 \%$ for sodium oxide. The total removal of impurities first increased from $98.31 \%$ to $98.86 \%$ and then decreased to $97.90 \%$, and the purity of the alumina rose from $99.9497 \%$ to $99.9661 \%$ and then fell to $99.9371 \%$, which indicated that the aging time had a greater impact on the impurity removal effect. When the aging temperature was low, the solution concentration viscosity was larger and the adsorption force of aluminum hydroxide crystals on impurities was larger, lowering the impurity removal rate, so extending the aging time is conducive to the removal of impurities. When the time was extended to more than $2 \mathrm{~h}$, the crystals slowly grew and agglomerated, and the inter-crystalline and crystal forces increased, which is not conducive to the removal of 
impurities. Thus, when the ageing time is $2 \mathrm{~h}$, the impurity $\mathrm{Na}_{2} \mathrm{O}$ content in the product alumina was lowest.

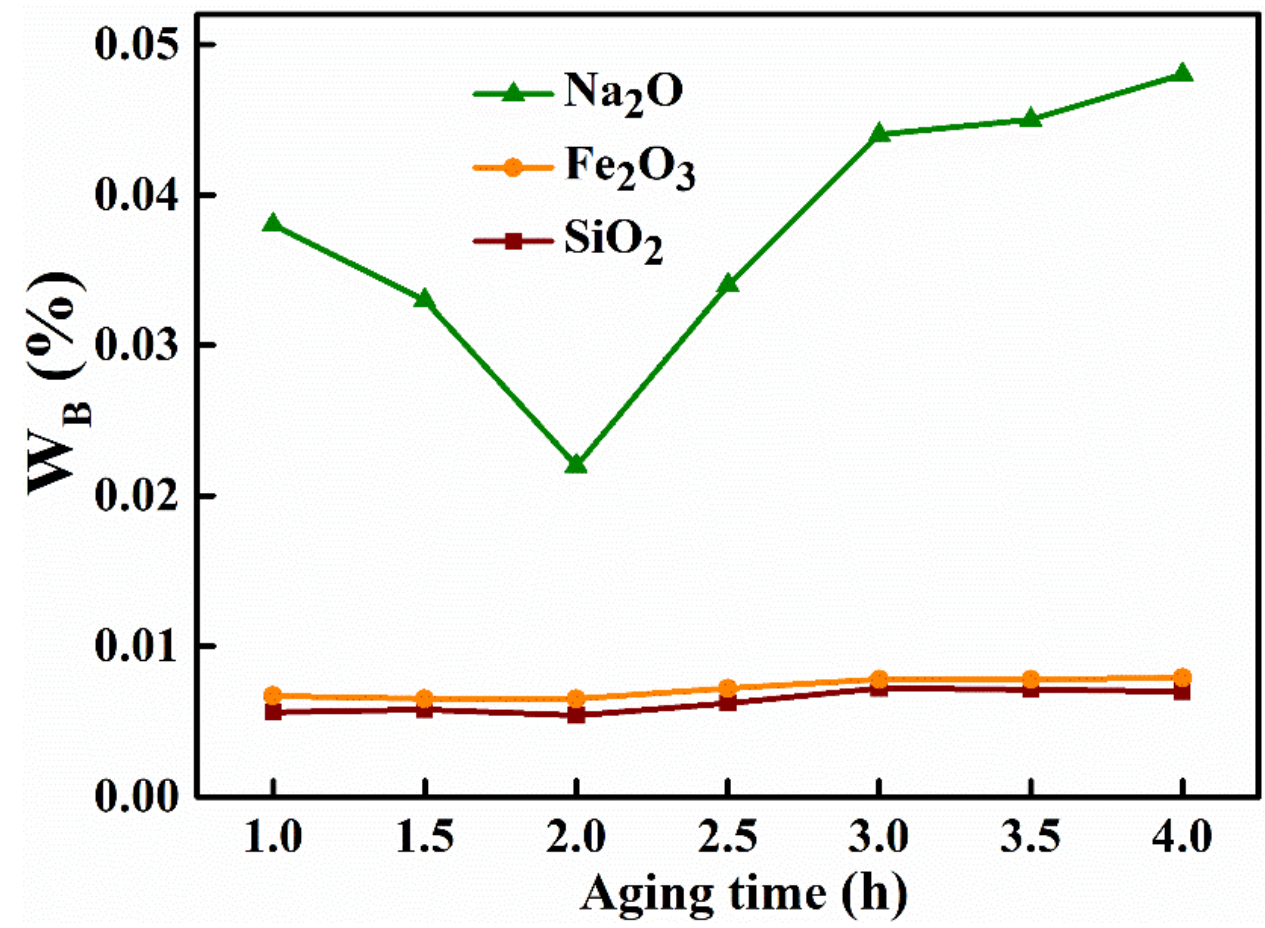

Figure 3. Effect of aging time on the impurity mass fraction in the product alumina.

Table 5. Effect of aging time on impurity removal efficiency and alumina purity.

\begin{tabular}{cccccc}
\hline \multirow{2}{*}{$\begin{array}{c}\text { Aging Time } \\
\text { (h) }\end{array}$} & \multicolumn{4}{c}{ Removal Efficiency (\%) } & Alumina Purity \\
\cline { 2 - 5 } & $\mathbf{F e}_{\mathbf{2}} \mathbf{O}_{\mathbf{3}}$ & $\mathbf{S i O}_{\mathbf{2}}$ & $\mathbf{N a}_{\mathbf{2}} \mathbf{O}$ & $\begin{array}{c}\text { Total Removal } \\
\text { Rate }\end{array}$ & $\begin{array}{c}\text { (\%) } \\
1\end{array}$ \\
\hline 1.5 & 99.42 & 99.55 & 93.45 & 98.31 & 99.9497 \\
2 & 99.44 & 99.54 & 94.31 & 98.48 & 99.9547 \\
2.5 & 99.44 & 99.57 & 96.21 & 98.86 & 99.9661 \\
3 & 99.37 & 99.50 & 94.14 & 98.41 & 99.9526 \\
3.5 & 99.32 & 99.42 & 92.41 & 98.03 & 99.9410 \\
4 & 99.32 & 99.43 & 92.24 & 97.99 & 99.9401 \\
\hline
\end{tabular}

\subsubsection{Type of Ammonium Salt}

To investigate the effect of ammonium salt type on the alumina powder quality, three alumina materials were prepared with a $\mathrm{NaAl}(\mathrm{OH})_{4}$ solution concentration of $60 \mathrm{~g} \mathrm{~L}^{-1}$, an ageing temperature of $60{ }^{\circ} \mathrm{C}$, an ageing time of $2 \mathrm{~h}$, a roasting temperature of $500{ }^{\circ} \mathrm{C}$, the mass concentrations of the ammonium oxalate, ammonium acetate and ammonium carbonate solutions of $75 \mathrm{~g} \mathrm{~L}^{-1}$. The nitrogen adsorption-desorption isotherms and poresize distribution plots of alumina materials washed with diverse ammonium salt solutions are shown in Figure 4; it shows that all the alumina particles showed the classical shape of a Type IV isotherm curve with an H1-type hysteresis loop, and all samples are known to be mesoporous materials, according to the IUPAC classification [52]. The effects of ammonium oxalate, ammonium acetate and ammonium carbonate on the impurity mass fraction and specific surface area of the product alumina are shown in Table 6; it shows that the type of ammonium salt had no obvious effect on the $\mathrm{Fe}_{2} \mathrm{O}_{3}$ and $\mathrm{SiO}_{2}$ mass ratio in the alumina product, but the type of ammonium salt had a large effect on the content and porosities of sodium impurities in the product. The sodium content of the alumina 
material prepared using ammonium carbonate as a sodium removal agent was only $0.022 \%$, with a specific surface area of $312.43 \mathrm{~m}^{2} \mathrm{~g}^{-1}$ and a pore volume of $0.43 \mathrm{~cm}^{3} \mathrm{~g}^{-1}$, whereas, the sodium impurity content using ammonium acetate and ammonium oxalate was as high as $0.054 \%$ and $0.050 \%$ respectively, with specific surface areas of $276.85 \mathrm{~m}^{2} \mathrm{~g}^{-1}$ and $252.20 \mathrm{~m}^{2} \mathrm{~g}^{-1}$, respectively, with pore volumes of $0.32 \mathrm{~cm}^{3} \mathrm{~g}^{-1}$ and $0.33 \mathrm{~cm}^{3} \mathrm{~g}^{-1}$, also respectively. This is due to the fact that ammonium carbonate can release more $\mathrm{NH}_{4}{ }^{+}$in the hydrolysis process, and $\mathrm{NH}_{4}{ }^{+}$can replace sodium ions in the reaction process and be absorbed by $\gamma-\mathrm{AlO}(\mathrm{OH})[53,54]$. After roasting to until the release of ammonia, it makes the solution more effective in removing sodium ions and achieves the best sodium removal. Gas release increased the specific surface area of the product and its porosity. On balance, the choice of ammonium carbonate washing is more appropriate.
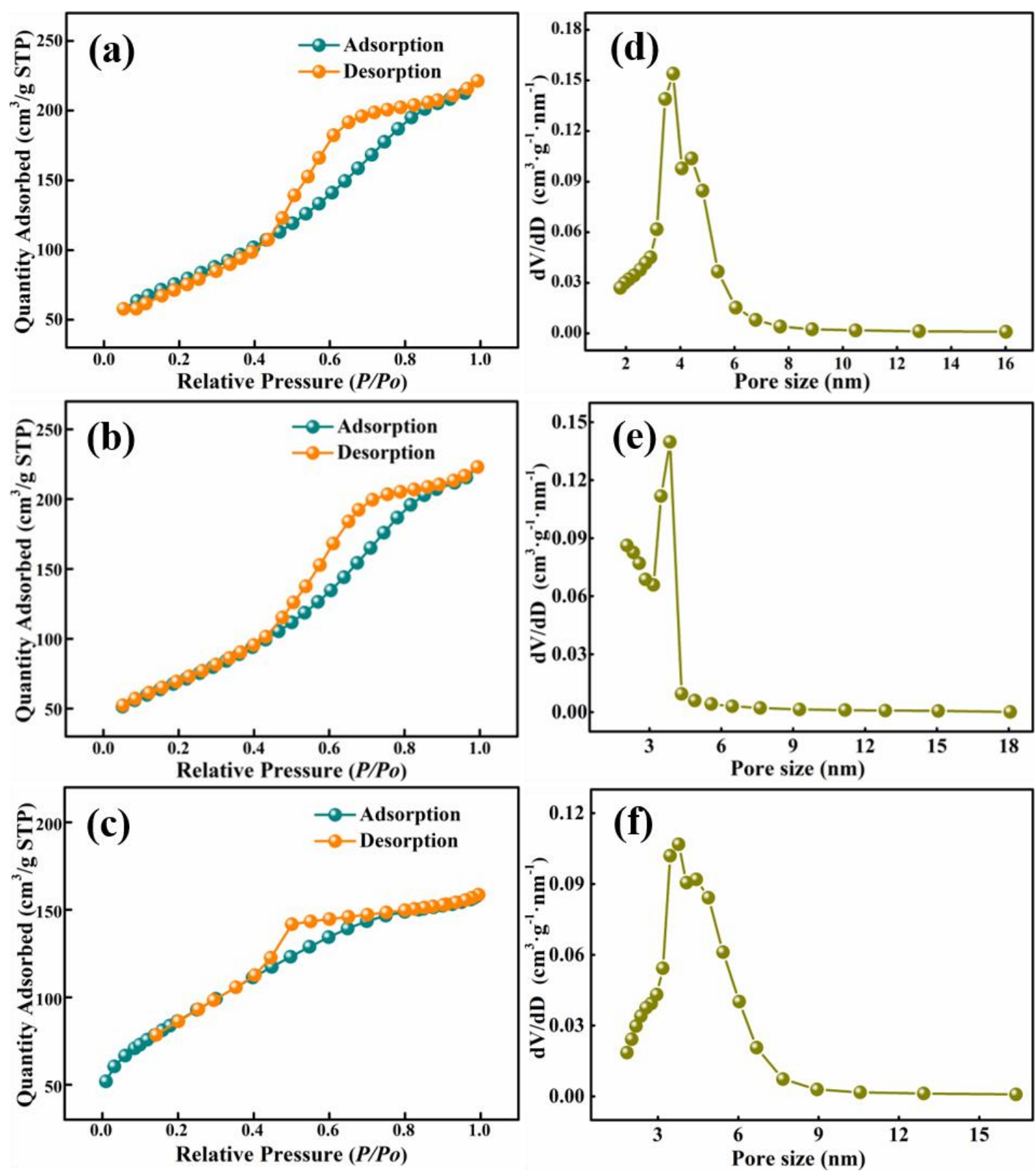

Figure 4. Nitrogen adsorption and desorption isotherms (a): $\left(\mathrm{NH}_{4}\right)_{2} \mathrm{CO}_{3}$, (b): $\mathrm{CH}_{3} \mathrm{COONH}_{4}$, (c): $\left(\mathrm{NH}_{4}\right)_{2} \mathrm{C}_{2} \mathrm{O}_{4}$; pore size distribution curves of different ammonium salts used in the products (d): $\left(\mathrm{NH}_{4}\right)_{2} \mathrm{CO}_{3},(\mathbf{e}): \mathrm{CH}_{3} \mathrm{COONH}_{4},(\mathbf{f}):\left(\mathrm{NH}_{4}\right)_{2} \mathrm{C}_{2} \mathrm{O}_{4}$. 
Table 6. Effect of ammonium salt type on the impurity mass, alumina purity and porosity the product alumina.

\begin{tabular}{|c|c|c|c|c|c|c|c|}
\hline \multirow{2}{*}{$\begin{array}{l}\text { Desodium } \\
\text { Agent }\end{array}$} & \multicolumn{4}{|c|}{ Content $\left(w_{B} / \%\right)$} & \multirow{2}{*}{$\begin{array}{l}\text { Specific Surface Area } \\
\qquad\left(\mathrm{m}^{2} \mathrm{~g}^{-1}\right)\end{array}$} & \multirow{2}{*}{$\begin{array}{l}\text { Pore Volume } \\
\left(\mathrm{cm}^{3} \mathrm{~g}^{-1}\right)\end{array}$} & \multirow{2}{*}{$\begin{array}{l}\text { Pore Size } \\
\text { (nm) }\end{array}$} \\
\hline & $\mathrm{Fe}_{2} \mathrm{O}_{3}$ & $\mathrm{SiO}_{2}$ & $\mathrm{Na}_{2} \mathrm{O}$ & $\mathrm{Al}_{2} \mathrm{O}_{3}$ & & & \\
\hline$\left(\mathrm{NH}_{4}\right)_{2} \mathrm{CO}_{3}$ & 0.0065 & 0.0054 & 0.022 & 99.9661 & 312.43 & 0.43 & 3.80 \\
\hline $\mathrm{CH}_{3} \mathrm{COONH}_{4}$ & 0.0063 & 0.0057 & 0.054 & 99.9340 & 276.85 & 0.32 & 3.86 \\
\hline$\left(\mathrm{NH}_{4}\right)_{2} \mathrm{C}_{2} \mathrm{O}_{4}$ & 0.0066 & 0.0054 & 0.050 & 99.9380 & 252.20 & 0.33 & 4.15 \\
\hline
\end{tabular}

\subsubsection{Mass Concentration of $\left(\mathrm{NH}_{4}\right)_{2} \mathrm{CO}_{3}$ Solution}

From the previous description, it is clear that ammonium carbonate had a good contribution to the purity and porosity of the material, so it is important to investigate the effect of different ammonium carbonate mass concentrations on the purity and porosity of the product. A collection of alumina materials was synthesized with a $\mathrm{NaAl}(\mathrm{OH})_{4}$ solution concentration of $60 \mathrm{~g} \mathrm{~L}^{-1}$, an ageing temperature of $60^{\circ} \mathrm{C}$, an ageing time of $2 \mathrm{~h}$, a roasting temperature of $500{ }^{\circ} \mathrm{C}$ and the mass concentrations of the $\left(\mathrm{NH}_{4}\right)_{2} \mathrm{CO}_{3}$ solutions of $25 \mathrm{~g} \mathrm{~L}^{-1}, 50 \mathrm{~g} \mathrm{~L}^{-1}, 75 \mathrm{~g} \mathrm{~L}^{-1}, 100 \mathrm{~g} \mathrm{~L}^{-1}$. As shown in Table 7 and Figure 5, with the increase of the mass concentration of ammonium carbonate from $25 \mathrm{~g} \mathrm{~L}^{-1}$ to $75 \mathrm{~g} \mathrm{~L}^{-1}$, the sodium oxide content decreased significantly (from $0.039 \%$ to $0.022 \%$ ), the sodium oxide removal rate increased (from $93.28 \%$ to $96.21 \%$ ) and the purity of alumina rose from $99.9478 \%$ to $99.9661 \%$ and then fell to $99.9653 \%$. When the mass concentration was increased to $100 \mathrm{~g} \mathrm{~L}^{-1}$, the sodium oxide content and removal rate remained essentially unchanged. Changing the mass concentration of ammonium carbonate did not affect the impurity contents of iron oxide or silica, nor their removal rates. At low concentrations, as the concentration increased (from $25 \mathrm{~g} \mathrm{~L}^{-1}$ to $75 \mathrm{~g} \mathrm{~L}^{-1}$ ), there was a gradual increase in the number of ammonium ions hydrolyzed from the solution, and, therefore, more sodium impurities were replaced by ammonium ions, which improved the purity of the material and also increased the specific surface area of the material. However, as the concentration became too high, the number of sodium impurities that could be replaced became a certain amount, so continuing to increase the concentration of ammonium carbonate later has no effect on the quality of the product. In summary, the HPMA powder synthesized by washing with $75 \mathrm{~g} \mathrm{~L}^{-1}$ ammonium carbonate solution had the highest purity and the largest specific surface area in terms of cost savings.

Table 7. Effect of mass concentration of ammonium carbonate solution on impurity removal efficiency, specific surface area and alumina purity.

\begin{tabular}{|c|c|c|c|c|c|c|}
\hline \multirow{2}{*}{$\begin{array}{l}\text { Concentration } \\
\qquad\left(\mathrm{g} \mathrm{L}^{-1}\right)\end{array}$} & \multicolumn{4}{|c|}{ Removal Efficiency (\%) } & \multirow[b]{2}{*}{$\begin{array}{c}\text { Alumina Purity } \\
(\%)\end{array}$} & \multirow{2}{*}{$\begin{array}{c}\text { Specific } \\
\text { Surface Are } \\
\left(\mathrm{m}^{2} \mathrm{~g}^{-1}\right)\end{array}$} \\
\hline & $\mathrm{Fe}_{2} \mathrm{O}_{3}$ & $\mathrm{SiO}_{2}$ & $\mathrm{Na}_{2} \mathrm{O}$ & $\begin{array}{c}\text { Total } \\
\text { Removal Rate }\end{array}$ & & \\
\hline 25 & 99.44 & 99.54 & 93.28 & 98.28 & 99.9478 & 205.86 \\
\hline 50 & 99.42 & 99.56 & 93.97 & 98.42 & 99.9528 & 276.54 \\
\hline 75 & 99.44 & 99.57 & 96.21 & 98.87 & 99.9661 & 312.43 \\
\hline 100 & 99.41 & 99.54 & 96.21 & 98.84 & 99.9653 & 311.59 \\
\hline
\end{tabular}

\subsubsection{Roasting Temperature}

To investigate the effect of firing temperature on the structure and properties of the products, four parts of $\mathrm{NaAl}(\mathrm{OH})_{4}$ solution were prepared, hydrochloric acid solution was added. The solution was aged at $60^{\circ} \mathrm{C}$ for $2 \mathrm{~h}$ and filtered, washed with ammonium carbonate solution (mass concentration of $75 \mathrm{~g} \mathrm{~L}^{-1}$ ), dried and roasted at $500{ }^{\circ} \mathrm{C}, 700{ }^{\circ} \mathrm{C}$, $900{ }^{\circ} \mathrm{C}$ and $1100{ }^{\circ} \mathrm{C}$ to obtain the product alumina. It can be seen from the XRD patterns (Figure 6) that the product is $\gamma-\mathrm{Al}_{2} \mathrm{O}_{3}$ with no significant change in the crystalline phase when roasted at $500-700{ }^{\circ} \mathrm{C}$; this partly occurs in the product-phase transformation from $\gamma-\mathrm{Al}_{2} \mathrm{O}_{3}$ to the $\theta-\mathrm{Al}_{2} \mathrm{O}_{3}$ crystalline phase when roasted at $900{ }^{\circ} \mathrm{C}$, and to the $\theta-\mathrm{Al}_{2} \mathrm{O}_{3}$ 
crystalline phase, which has a small specific surface area (JCPDF Card: No. 11-0517) and is completely formed at $1100{ }^{\circ} \mathrm{C} . \theta-\mathrm{Al}_{2} \mathrm{O}_{3}$ is the most stable tripartite crystalline system among all alumina phases; it has a low specific surface area and weak chemical activity, so it is not suitable for the preparation of adsorbents or catalysts. Therefore, it is not suitable for the preparation of adsorbents or catalysts.

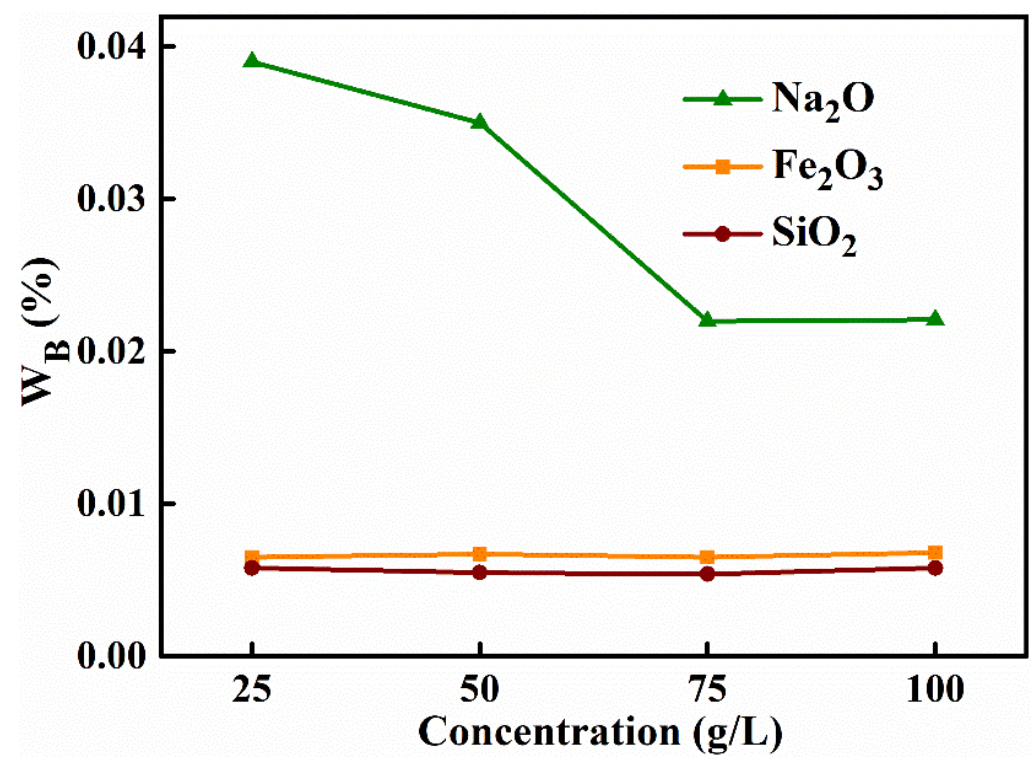

Figure 5. Effect of the mass concentration of ammonium carbonate solution on the mass fraction of the product alumina.
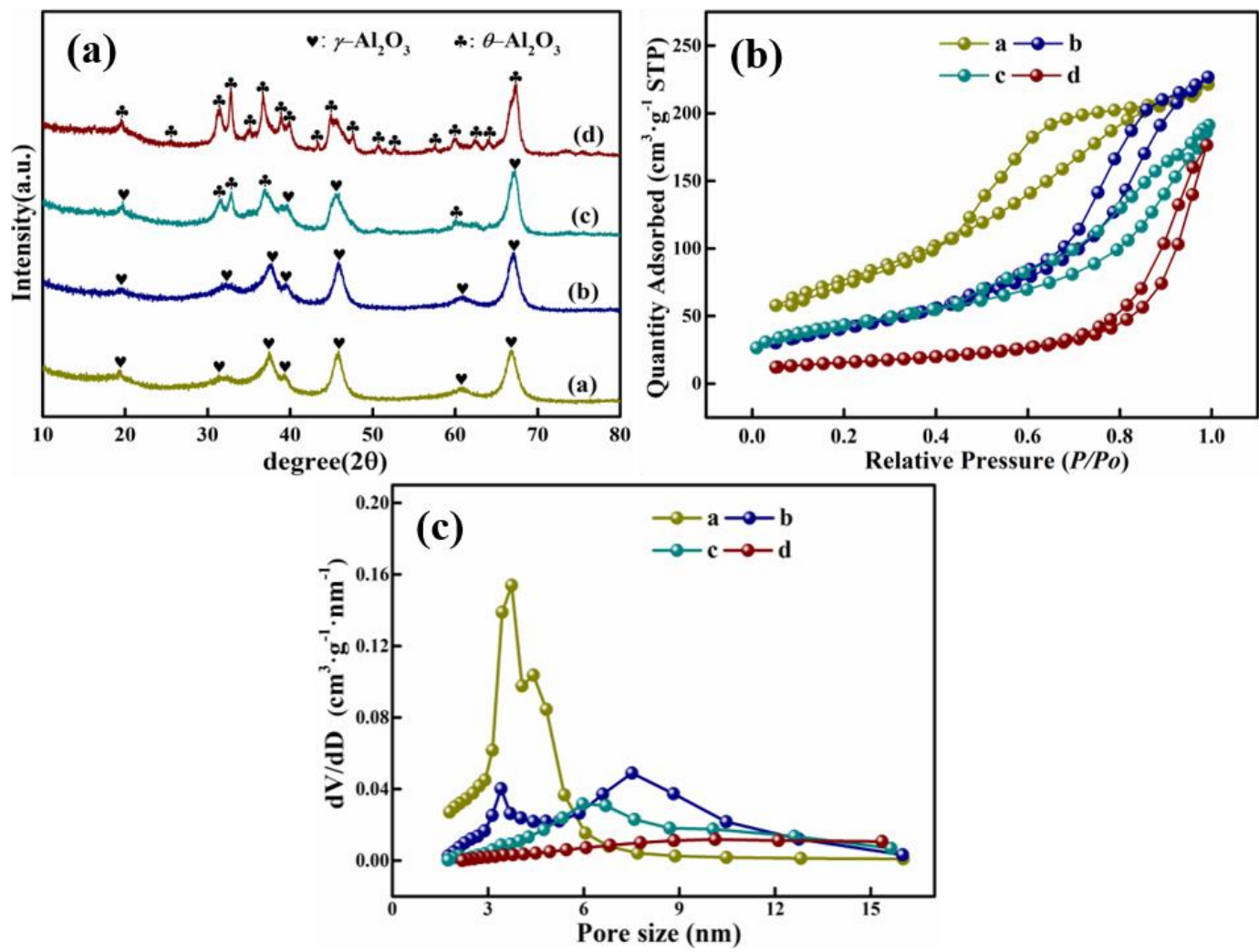

Figure 6. XRD patterns; (a) nitrogen adsorption-desorption isotherms; (b) pore-size distribution curves (c) of HPMA products obtained at different roasting temperatures: (a) $500{ }^{\circ} \mathrm{C}$; (b) $700{ }^{\circ} \mathrm{C}$; (c) $900{ }^{\circ} \mathrm{C}$. 
The nitrogen adsorption-desorption isotherms and the pore size distribution plots of alumina materials calcined for $4 \mathrm{~h}$ at various temperatures are shown in Figure $6 \mathrm{~b}, \mathrm{c}$. The alumina particles roasted at various temperatures show the classical shape of a Type IV isotherm curve with an H1-type hysteresis loop, and all samples are known to be mesoporous materials according to the IUPAC classification [52]. It can be revealed from Table 8 that an increase in calcination temperature from $500{ }^{\circ} \mathrm{C}$ to $1100{ }^{\circ} \mathrm{C}$ caused the pore size of the alumina material to increase and the number of pores to decrease. This is because under high temperature conditions, the entire pore structure on the surface of the material collapses and agglomerates, as shown in TEM images (Figure 7), resulting in a dramatic reduction in specific surface area and total pore volume (the specific surface area was reduced from $312.43 \mathrm{~m}^{2} \mathrm{~g}^{-1}$ to $88.52 \mathrm{~m}^{2} \mathrm{~g}^{-1}$, pore volume $0.48 \mathrm{~cm}^{3} \mathrm{~g}^{-1}$ to $0.08 \mathrm{~cm}^{3} \mathrm{~g}^{-1}$.) Thus, the HPMA material prepared by roasting at $500{ }^{\circ} \mathrm{C}$ had the largest specific surface area and pore volume, with more active chemistry sites for catalysts and adsorbents.

Table 8. Effect of roasting temperature on the specific surface area and pore volume.

\begin{tabular}{cccc}
\hline Temperature & $\begin{array}{c}\text { Specific Surface } \\
\text { Area }\left(\mathbf{m}^{\mathbf{2}} \mathbf{g}^{-\mathbf{1}}\right)\end{array}$ & $\begin{array}{c}\text { Pore Volume } \mathbf{( c m}^{\mathbf{3}} \\
\left.\mathbf{g}^{-\mathbf{1}}\right)\end{array}$ & Pore Diameter (nm) \\
\hline $500^{\circ} \mathrm{C}$ & 312.43 & 0.48 & 3.80 \\
$700^{\circ} \mathrm{C}$ & 199.35 & 0.36 & 5.36 \\
$900^{\circ} \mathrm{C}$ & 144.34 & 0.19 & 8.66 \\
$1100^{\circ} \mathrm{C}$ & 88.52 & 0.08 & 10.03 \\
\hline
\end{tabular}


Figure 7. TEM images of HPMA materials obtained at different roasting temperatures: (a) $500{ }^{\circ} \mathrm{C}$; (b) $700{ }^{\circ} \mathrm{C}$; (c) $900{ }^{\circ} \mathrm{C}$; (d) $1100{ }^{\circ} \mathrm{C}$. 


\subsection{Characteristics of High Purity Mesoporous Alumina}

Gamma-phase high-purity mesoporous alumina (HPMA) materials with high specific surface areas were successfully prepared by the direct ageing and ammonium salt replacement methods. As the sodium hydroxide solution dissolved the industrial aluminum hydroxide, the $\mathrm{Si}$ and $\mathrm{Fe}$ impurities could be effectively removed by dissolving the industrial aluminum hydroxide with sodium hydroxide which has been described in Section 3.1.1. The solution equilibrium was disrupted by the direct ageing of dilute hydrochloric acid drops into the reaction system. $\gamma-\mathrm{AlO}(\mathrm{OH})$ crystals are rapidly generated with fine crystal particles, resulting in weak intermolecular forces; therefore, the adsorption of impurities was weak, while the fine particles facilitated an increase in the specific surface area of the material. Finally, by adding an excess of ammonium salt solution, the dissociated $\mathrm{NH}_{4}{ }^{+}$could replace the sodium ions during the reaction to produce $\mathrm{Na}_{2} \mathrm{CO}_{3}$ [55]. $\mathrm{NH}_{4}{ }^{+}$can be absorbed by $\gamma-\mathrm{AlO}(\mathrm{OH})[53,54]$, which plays a significant desaturation role, and ammonium ions on the surface of $\gamma-\mathrm{AlO}(\mathrm{OH})$ were released in the form of ammonia molecules during calcination, increasing the porosity of the material and thus improving the specific surface area. The main chemical reactions in the preparation process are as follows:

$$
\begin{aligned}
& \mathrm{Al}(\mathrm{OH})_{3}+\mathrm{NaOH} \rightarrow \mathrm{NaAl}(\mathrm{OH})_{4} ; \\
& \mathrm{Fe}_{2} \mathrm{O}_{3}+2 \mathrm{NaOH}+3 \mathrm{H}_{2} \mathrm{O} \rightarrow 2 \mathrm{NaFe}(\mathrm{OH})_{4} ; \\
& \mathrm{SiO}_{2}+2 \mathrm{NaOH} \rightarrow \mathrm{Na}_{2} \mathrm{SiO}_{3}+\mathrm{H}_{2} \mathrm{O} ; \\
& 2 \mathrm{NaAl}(\mathrm{OH})_{4}+1.7 \mathrm{Na}_{2} \mathrm{SiO}_{3} \rightarrow \mathrm{Na}_{2} \mathrm{O} \cdot \mathrm{Al}_{2} \mathrm{O}_{3} \cdot 1.7 \mathrm{SiO}_{2} \cdot \mathrm{nH}_{2} \mathrm{O} \downarrow+3.4 \mathrm{NaOH}+3 \mathrm{H}_{2} \mathrm{O} \text {; } \\
& \mathrm{NaAl}(\mathrm{OH})_{4}+\mathrm{HCl} \rightarrow \mathrm{Al}(\mathrm{OH})_{4}{ }^{-}+\mathrm{NaCl}+\mathrm{H}^{+} \text {; } \\
& \mathrm{NaAlO}_{2} \rightarrow \mathrm{NaOH}+\mathrm{Al}(\mathrm{OH})_{4}{ }^{-} \text {; } \\
& \mathrm{NaOH}+\left(\mathrm{NH}_{4}\right)_{2} \mathrm{CO}_{3} \rightarrow \mathrm{Na}_{2} \mathrm{CO}_{3}+\mathrm{NH}_{3} \cdot \mathrm{H}_{2} \mathrm{O} ; \\
& \left(\mathrm{NH}_{4}\right)_{2} \mathrm{CO}_{3} \rightarrow 2 \mathrm{NH}_{4}{ }^{+}+\mathrm{CO}_{3}{ }^{2-} \text {; } \\
& \mathrm{Al}(\mathrm{OH})_{4}{ }^{-} \rightarrow \gamma-\mathrm{AlO}(\mathrm{OH}) \cdot \mathrm{nH}_{2} \mathrm{O}+(1-\mathrm{n}) \mathrm{H}_{2} \mathrm{O} \text {; } \\
& 2 \gamma-\mathrm{AlO}(\mathrm{OH}) \cdot \mathrm{nH}_{2} \mathrm{O} \rightarrow \gamma-\mathrm{Al}_{2} \mathrm{O}_{3}+2(1-\mathrm{n}) \mathrm{H}_{2} \mathrm{O} \text {; }
\end{aligned}
$$

The impurity mass ratios, excellent removal rates and surface physical properties of the HPMA materials synthesized under optimum conditions with initial $\mathrm{NaAl}(\mathrm{OH})_{4}$ solution concentration of $60 \mathrm{~g} \mathrm{~L}^{-1}$, ageing temperature of $60^{\circ} \mathrm{C}$, ageing time of $2 \mathrm{~h}$, roasting temperature of $500{ }^{\circ} \mathrm{C}$ and the mass concentration of the $\left(\mathrm{NH}_{4}\right)_{2} \mathrm{CO}_{3}$ solution of $75 \mathrm{~g} \mathrm{~L}^{-1}$ are shown in Table 9 revealing that the mass fractions of residual $\mathrm{Fe}_{2} \mathrm{O}_{3}, \mathrm{SiO}_{2}$ and $\mathrm{Na}_{2} \mathrm{O}$ in the alumina products were $0.0065 \%, 0.0054 \%$ and $0.022 \%$ respectively, with removal rates of $99.44 \%, 99.57 \%$ and $96.21 \%$ respectively, which showed that the purity of the product was as great as $99.9661 \%$ and the total removal rate of impurities was $98.87 \%$. Moreover, the specific surface area, pore volume and pore size of the material were $312.43 \mathrm{~m}^{2} \mathrm{~g}^{-1}$, $0.48 \mathrm{~cm}^{3} \mathrm{~g}^{-1}$ and $3.80 \mathrm{~nm}$, respectively, indicating that the material prepared was HPMA with high purity and porosity, which can be widely used in the preparation of adsorbents.

Table 9. Impurity mass fraction in the product mesoporous alumina and its porosity.

\begin{tabular}{cccccccc}
\hline Impurities & $\mathrm{Fe}_{\mathbf{2}} \mathbf{O}_{\mathbf{3}}$ & $\mathrm{SiO}_{\mathbf{2}}$ & $\mathrm{Na}_{\mathbf{2}} \mathbf{O}$ & $\begin{array}{c}\text { Total } \\
\text { Values }\end{array}$ & $\begin{array}{c}\text { Specific Surface } \\
\text { Area }\left(\mathbf{m}^{\mathbf{2}} \mathbf{g}^{-\mathbf{1}}\right)\end{array}$ & $\begin{array}{c}\text { Pore Volume } \\
\left(\mathbf{c m}^{\mathbf{3}} \mathbf{g}^{-\mathbf{1}}\right)\end{array}$ & $\begin{array}{c}\text { Pore Size } \\
(\mathbf{n m})\end{array}$ \\
\hline Content $\left(w_{B} / \%\right)$ & 0.0065 & 0.0054 & 0.022 & 0.0339 & & & \\
\hline Remove rate $(\%)$ & 99.44 & 99.57 & 96.21 & 98.87 & 312.43 & 0.48 & 3.80 \\
\hline
\end{tabular}

XRD patterns (Figure $8 \mathrm{a}$ ) showed that the diffraction peaks at $2 \theta=19.439^{\circ}, 31.951^{\circ}$, $37.648^{\circ}, 39.398^{\circ}, 45.854^{\circ}, 60.878^{\circ}$ and $67.029^{\circ}$ correspond to the (111), (220), (311), (222), (400), (511) and (440) crystals of $\gamma-\mathrm{Al}_{2} \mathrm{O}_{3}$ (JCPDS card NO. 10-0425), respectively. There was 
not any other significant diffraction peak, indicating that this alumina with a cubic structure had the absolute high purity [56]. All diffraction peaks exhibited a high degree of broadness for their fine natures, and less degeneracy in the crystal. According to the Debye-Scherrer equation [57], $D=k \lambda / \beta \cos \theta$, where $k$ is a constant, $\theta$ is the diffraction angle, $\lambda$ is the $X$-ray wavelength and $\beta$ is the full width at half maximum (FWHM), the principal grain sizes of $\gamma-\mathrm{Al}_{2} \mathrm{O}_{3}$ calculated from the full width at half maximum of the isolated (311), (400) and (440) diffraction peaks are $14.3 \mathrm{~nm}, 12.8 \mathrm{~nm}$ and $16.7 \mathrm{~nm}$, respectively.
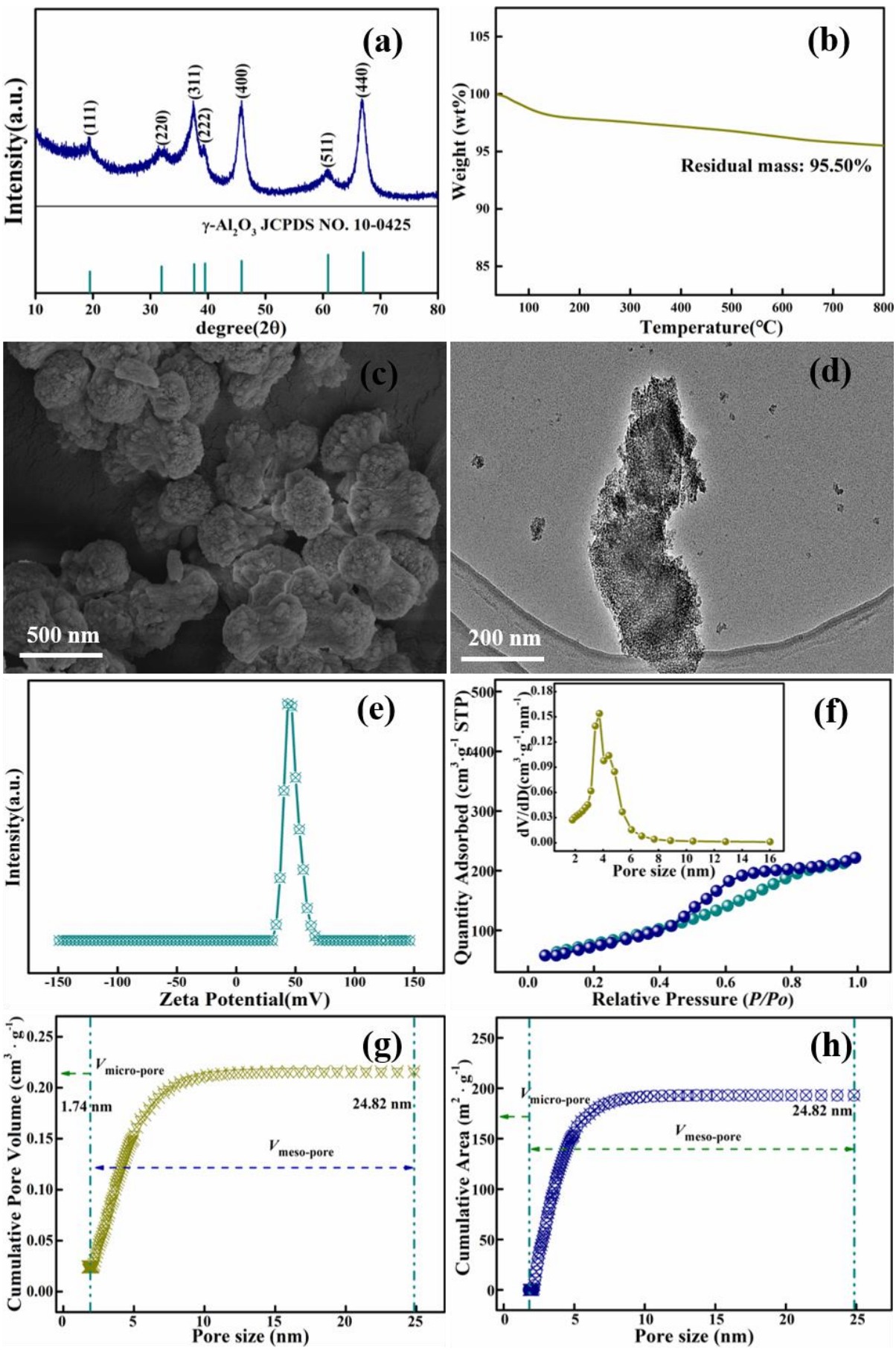

Figure 8. XRD pattern (a); TGA diagram (b); SEM image (c); TEM picture (d); Zeta potential plots (e); Nitrogen adsorption-desorption isotherms (f); cumulative pore volume (g); and cumulative area (h) through BJH kernels of mesoporous HPA material synthesized under optimal conditions. The inset of (f) shows the pore-size distribution curves in the BJH model. 
Figure $8 \mathrm{~b}$ shows the TGA diagram of the adsorbent HPMA material. As can be seen from the graph, there was no distinctive weight loss with the temperature rising from room temperature to $800{ }^{\circ} \mathrm{C}$, proving that the mesoporous material produced has good thermal stability, which can be applied in the adsorption of Congo Red.

It can be seen from the SEM picture (Figure 8c) and TEM image (Figure $8 \mathrm{~d}$ ) that the product alumina was porous, small particles with clear individual particles, less agglomeration and many fine pore channels on the surface of the product, which increased the specific surface area of the material, enhancing the surface energy and surface bonding energy, which can be easily stabilized by bonding with other atoms, thus increasing the chemical activity of HPMA. The greater chemical activity induced corresponding changes in atomic transport and conformation on the surface of the alumina nanoparticles, leading to changes in the electron spin conformation and electronic energy spectrum on the surface of the HPMA material particles, features that contribute to the improved adsorption performance of HPMA. The size of the crystals was essentially in the range of $200 \mathrm{~nm}$ to $500 \mathrm{~nm}$. Zeta potential is an important parameter in measuring the strength of mutual repulsion or attraction between particles; as the absolute value of the zeta potential rises, the degree of dispersion is much greater than the degree of aggregation, making the molecular surface attraction greater than the repulsion. The zeta potential plots of the as-synthesized HMPA nano-materials are shown in Figure 8e, showing that the zeta potential value of the HPMA particles was $46 \pm 3 \mathrm{mV}$, with potential values in the range of $40-60 \mathrm{mV}$, revealing that the adsorbent had a positive charge on its surface with outstanding surface stability [58] and excellent adsorption property for CR.

Nitrogen adsorption-desorption isotherms are shown in Figure 8f; according to the IPUAC classification [52], the HPMA powder shows a typical type IV isotherm curve shape with an H1-type hysteresis loop, which is due to the slight sintering of mesoporous $\gamma-\mathrm{Al}_{2} \mathrm{O}_{3}$ at this calcination temperature. The pore size distribution curve, cumulative pore volume plot and cumulative surface area curves of the mesoporous $\gamma-\mathrm{Al}_{2} \mathrm{O}_{3}$ material obtained by the $\mathrm{BJH}$ model are shown in the inset of Figure $8 \mathrm{f}-\mathrm{h}$, respectively. As can be seen from the pore size distribution plots, the pore size of the material was mainly distributed in the range of $2-16 \mathrm{~nm}$, while the cumulative pore volume curves and cumulative surface area curves of the material were in the range of 2-24.82 $\mathrm{nm}$. Mesoporous materials are defined as pore sizes in the range of 2-50 $\mathrm{nm}$ porous material [59], therefore, the product was a porous, highly dispersed solid material with a large specific surface area and high activity, which confer good catalytic and adsorption properties [1-5].

\subsection{HPMA Materials Adsorption of Congo Red Analysis}

Adsorption kinetics studies play a critical role in adsorption studies, as they can predict very accurately the rate at which pollutants are removed during the adsorption process. Additionally, adsorption kinetic studies can also provide quite pragmatic data when speculating on adsorption mechanisms. The kinetic curve for the adsorption of Congo Red dye in the HPMA sample is shown in Figure 9a. The adsorption process was carried out at $25^{\circ} \mathrm{C}$, the concentration of Congo Red dye was fixed at $250 \mathrm{mg} \mathrm{L}^{-1}$ and the amount of adsorbent was $100 \mathrm{mg}$. It shows that at the beginning of the process (from 0-10 $\mathrm{min}$ ), adsorption proceeded very rapidly, but after saturation of the active centers from the adsorbent surface, adsorption remained unchanged. This is due to the fact that the remained vacant sites were difficult to occupy, due to repulsive forces between the dye adsorbed on the surface of HPMA and the solution phase [60,61]. The adsorption equilibrium was reached in about $60 \mathrm{~min}$, the adsorption amount was $492.19 \mathrm{mg} \mathrm{g}^{-1}$ at that time, and the dye removal rate was as high as $98.44 \%$. As discussed in the nitrogen adsorption-desorption analysis, a desodium agent can enahnce the pore structure of the material to increase the specific surface area of the material, and thus enhance its chemistry activity, increasing adsorption capacity. The adsorption kinetic data are in good agreement with this speculation. It is suggested that this HPMA material has excellent adsorption 
performance for $\mathrm{CR}$ and the adsorption rate is very fast, thus, it is suitable for wide use in the adsorption of CR in organic dyes.
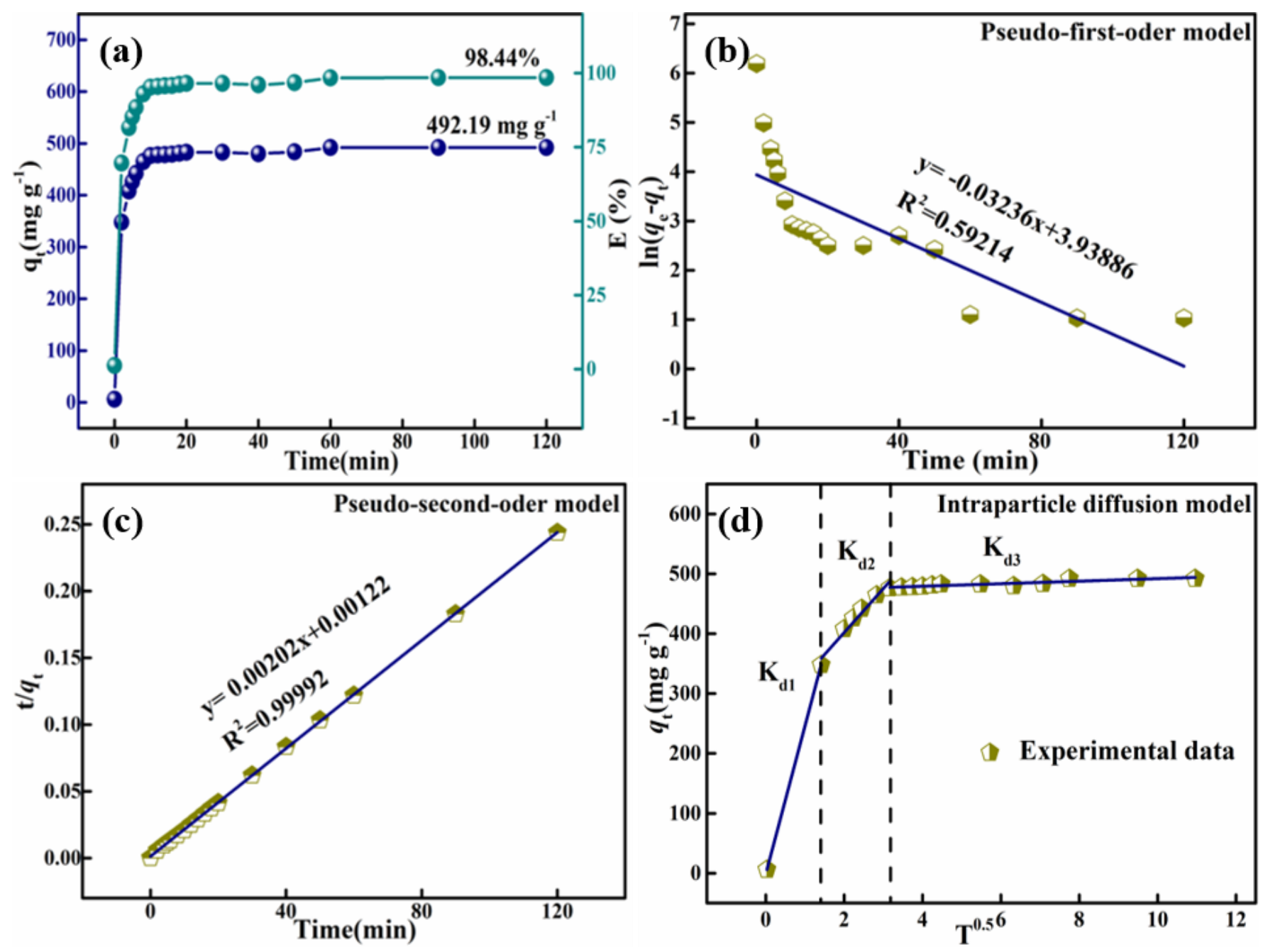

Figure 9. Variation in adsorption capacity with adsorption time for CR (a); pseudo-first order kinetics (b); pseudo-second order kinetics (c); intra-particle diffusion kinetics (d) for adsorption of CR on samples HPMA $\left(\mathrm{T}=25^{\circ} \mathrm{C}\right.$, adsorbent mass $=100 \mathrm{mg}, \mathrm{CR}$ concentration $=250 \mathrm{mg} \mathrm{L}^{-1}$, and $\left.\mathrm{pH}=4\right)$.

Having analyzed the kinetic characteristics of the adsorbent HPMA for Congo Red dye, it is possible, in practice, to design the Congo Red adsorption process in solution. Typically, the frequently used kinetic models are as follows:

Pseudo-first-order model:

$$
\ln \left(q_{e}-q_{t}\right)=\ln q_{e}-\mathrm{K}_{1} \mathrm{t}
$$

Pseudo-second-order model:

$$
\mathrm{t} / q_{t}=1 / \mathrm{K}_{2} q^{2}{ }_{e}+\mathrm{t} / q_{e}
$$

in which $q_{e}$ and $q_{t}\left(\mathrm{mg} \mathrm{g}^{-1}\right)$ are, respectively, the adsorption capacities at equilibrium and at any time $t(\mathrm{~min})$.

The kinetic behavior of Congo Red adsorption on the synthesized HPMA was investigated using pseudo-first-order and pseudo-second-order kinetic models. The obtained kinetic parameters for adsorption are listed in Table 10 and these fitted curves are shown in the Figure 9b,c. Apparently, when using the pseudo-first-order kinetic model, the experi- 
mental value $\left(q_{e}\right)$ was much higher than the calculated value, probably due to the fact that the correlation coefficient, $R^{2}$, was as low as 0.59214 . Contrarily, the pseudo-second-order kinetic model was used to obtain the calculated value of 495.05 , close to the experimental value of 495, and the correlation coefficient $R^{2}$ was as high as 0.99992 , indicating that the adsorption process of Congo Red on synthetic HPMA materials is very consistent with the pseudo-second-order kinetic model.

Table 10. Kinetic parameters for adsorption of CR on the HPMA powder.

\begin{tabular}{cccc}
\hline$q_{\text {e-exp }}\left(\mathrm{mg} \mathrm{g}^{-1}\right)$ & \multicolumn{3}{c}{495} \\
\hline \multirow{2}{*}{ pseudo-first-oder model } & $q_{e-c a l}\left(\mathrm{mg} \mathrm{g}^{-1}\right)$ & $\mathbf{K}_{\mathbf{1}}\left(\mathbf{m i n}^{-1}\right)$ & $R^{2}$ \\
& 51.36 & 0.03236 & 0.59214 \\
\hline \multirow{2}{*}{ pseudo-second-oder model } & $q_{e-c a l}\left(\mathbf{m g ~ g}^{-1}\right)$ & $\mathbf{K}_{\mathbf{2}}\left(\mathbf{m i n}^{-1}\right)$ & $R^{2}$ \\
& 495.05 & 0.00334459 & 0.99992 \\
\hline
\end{tabular}

$\mathbf{K}_{\mathbf{1}}$ is the kinetic parameter fitted by the 1st-order model. $\mathbf{K}_{\mathbf{2}}$ is the kinetic parameter fitted by 2nd-order model.

In order to further investigate the internal particle diffusion, the experimental data were fitted with the internal particle diffusion model proposed by Weber and Morris [62]. For adsorbents, the distribution of the adsorbed amount with respect to time $t^{0.5}$ is more regular than the distribution with respect to contact time $t$. This model was obtained by fitting the following equation.

$$
q_{t}=\mathrm{K}_{\mathrm{di}} \mathrm{t}^{0.5}+\mathrm{C}_{\mathrm{i}}
$$

where $\mathrm{K}_{\mathrm{di}}$ is the rate constant for stage $\mathrm{i}$, calculated from the slope of the curve of $q_{t}$ with respect to $t^{0.5} \cdot C_{i}$ is the intercept of stage $i$; the larger the intercept, the more pronounced the boundary layer effect will be. For the internal particle diffusion model, $q_{t}$ should be linear with respect to $\mathrm{t}^{0.5}$, and if the curve passes through the origin point, the velocity-limiting process only depends on the internal particle diffusion rate. A linear fit of the internal particle diffusion model for the adsorption of Congo Red was shown in Figure 9d, where it can be seen that the whole adsorption process can be divided into three steps. From this model, transient adsorption, which can also be referred to as external adsorption, occurs in the solution during the first $2 \mathrm{~min}$ when the rate of adsorption is high due to the high initial concentration of Congo Red. The rate of adsorption then decreases significantly during the second phase, which is known as the progressive or slow adsorption phase, and it is the stage wherein the rate of adsorption is limited. The last one is the final equilibrium stage, wherein the $\mathrm{CR}$ concentration is at its lowest and therefore the internal particle diffusion rate is at its slowest. The phenomenon $\mathrm{K}_{\mathrm{d} 1}<\mathrm{K}_{\mathrm{d} 2}<\mathrm{K}_{\mathrm{d} 3}$ was shown in Table 11 .

Table 11. Intra-particle diffusion model constants and correlation coefficients for adsorption of CR.

\begin{tabular}{ccc}
\hline $\mathrm{K}_{\mathrm{d} \mathbf{1}}\left(\min ^{-1}\right)$ & $\mathrm{C}_{\mathbf{1}}$ & $\boldsymbol{R}_{\mathbf{1}}{ }^{2}$ \\
247.343 & -1.82167 & 1 \\
\hline $\mathrm{K}_{\mathrm{d} \mathbf{2}}\left(\min ^{-1}\right)$ & $\mathrm{C}_{\mathbf{2}}$ & $\boldsymbol{R}_{\mathbf{2}}{ }^{2}$ \\
73.47937 & 254.92449 & 0.95626 \\
\hline $\mathrm{K}_{\mathrm{d} 3}\left(\min ^{-1}\right)$ & $\mathrm{C}_{\mathbf{3}}$ & $\boldsymbol{R}_{\mathbf{3}}{ }^{2}$ \\
2.11518 & 470.82288 & 0.82684 \\
\hline
\end{tabular}

$\mathbf{K}_{\mathrm{di}}$ is the value of slope fitted by I-D model; $\mathbf{C}_{\mathbf{i}}$ is the corresponding intercept value.

The adsorption isotherm is a mathematical model used to describe the adsorbed species distribution on the adsorbent surface of the adsorbent $[63,64]$. The nonlinear isotherm models proposed by Langmuir [65], Freundlich [66] and Temkin [67] were used to investigate the adsorption mechanism. These models were chosen to understand whether adsorption occurs in monolayers (Langmuir), multilayers (Freundlich) or by diffusion (Temkin). 
Langmuir model:

$$
q_{e}=q_{m} K_{L} C_{e} /\left(1+K_{L} C_{e}\right)
$$

where $C_{e}(\mathrm{mg} / \mathrm{L})$ is the equilibrium concentration of solute, $q_{e}(\mathrm{mg} / \mathrm{g})$ is the equilibrium adsorption capacity of the adsorbent, $q_{m}(\mathrm{mg} / \mathrm{g})$ is the saturated adsorption amount of the adsorbent and $K_{L}(\mathrm{~L} / \mathrm{mg})$ is the Langmuir adsorption constant.

Freundlich model:

$$
\ln q_{e}=\ln K_{F}+(1 / n) \ln C_{e}
$$

where $K_{F}\left(\mathrm{~L} \mathrm{mg}^{-1}\right)$ and $n$ are Freundlich isotherm constants, which refer to the capacity and intensity of the adsorption.

Temkin model:

$$
q_{e}=R T \ln K_{T} / b+R T \ln C_{e} / b
$$

where $K_{T}\left(\mathrm{~L} \mathrm{mg}^{-1}\right)$ and $b$ are Temkin isotherm constants, $R(\mathrm{~J} /(\mathrm{mol} \mathrm{K}))$ is the ideal gas constant, $T(\mathrm{~K})$ is the adsorption temperature.

To study the adsorption isotherms, $100 \mathrm{mg}$ of adsorbent was weighed and dispersed in 200-mL CR solutions with mass concentrations ranging from $50-1750 \mathrm{mg} \mathrm{L}^{-1}$. The relation between the adsorption capacities, removal efficiency of the adsorbents and the initial concentrations of CR was given by the adsorption isotherm in Figure 10. It could be observed that the adsorption capacities of the high-porosity HPMA nanoparticles increased with increase in the initial CR mass concentration and then remained at $1984.64 \mathrm{mg} \mathrm{g}^{-1}$, while its removal efficiency decreased. The linear plots of the Langmuir model, Freundlich model and Temkin model of the adsorption of CR are given in Figure 10b- $\mathrm{d}$ and the adsorption isotherms parameters for adsorption of CR on the HPMA powder are shown in Table 12. It shows that the value of $R^{2}$ of the Langmuir model for the prepared high-porosity HPMA material is 0.99972 , while the $R^{2}$ values of Freundlich model and Temkin model for this material were 0.86148 and 0.97039 , respectively. Therefore, the adsorptions of the prepared high porosity HPMA material followed the Langmuir isotherm model closely. which indicates that the adsorption between the sample and Congo Red was a physical adsorption of a single molecular layer on its surface and that no chemical reaction took place [5]. Furthermore, the linearization fitted with the Langmuir isotherm model of the equations for the prepared material was $y=0.000486898 x+0.01022$, and the $q_{m}$ value for the adsorption of CR by the prepared high porosity HPMA material calculated with Langmuir isotherm model was $2053.818 \mathrm{mg} \mathrm{g}^{-1}$, which was a little higher than the experiment data of $1984.64 \mathrm{mg} \mathrm{g}^{-1}$.

Table 12. Adsorption isotherms parameters for adsorption of CR on the HPMA powder.

\begin{tabular}{cccc}
\hline \multirow{2}{*}{ Langmuir model } & $\boldsymbol{q}_{m}\left(\mathbf{m g ~ g}^{-\mathbf{1}}\right)$ & $\mathbf{K}_{\mathbf{L}}$ & $R^{\mathbf{2}}$ \\
\cline { 2 - 4 } & 2053.818 & 0.0476 & 0.99972 \\
\hline \multirow{2}{*}{ Freundlich model } & $\mathbf{K}_{\mathbf{F}}\left(\mathbf{m g}^{\mathbf{1 - ( 1 / n )}} \mathbf{L}^{\mathbf{1 / n}} \mathbf{g}^{-\mathbf{1}}\right)$ & $\mathbf{n}$ & $\boldsymbol{R}^{\mathbf{2}}$ \\
\cline { 2 - 4 } & 259.755 & 2.882 & 0.86148 \\
\hline \multirow{2}{*}{ Temkin model } & $\mathbf{K}_{\mathrm{T}}\left(\mathbf{L ~ m g}^{-\mathbf{1}}\right)$ & $\mathbf{b}$ & $\boldsymbol{R}^{\mathbf{2}}$ \\
\cline { 2 - 4 } & 1.021 & 7.1853 & 0.97039 \\
\hline
\end{tabular}



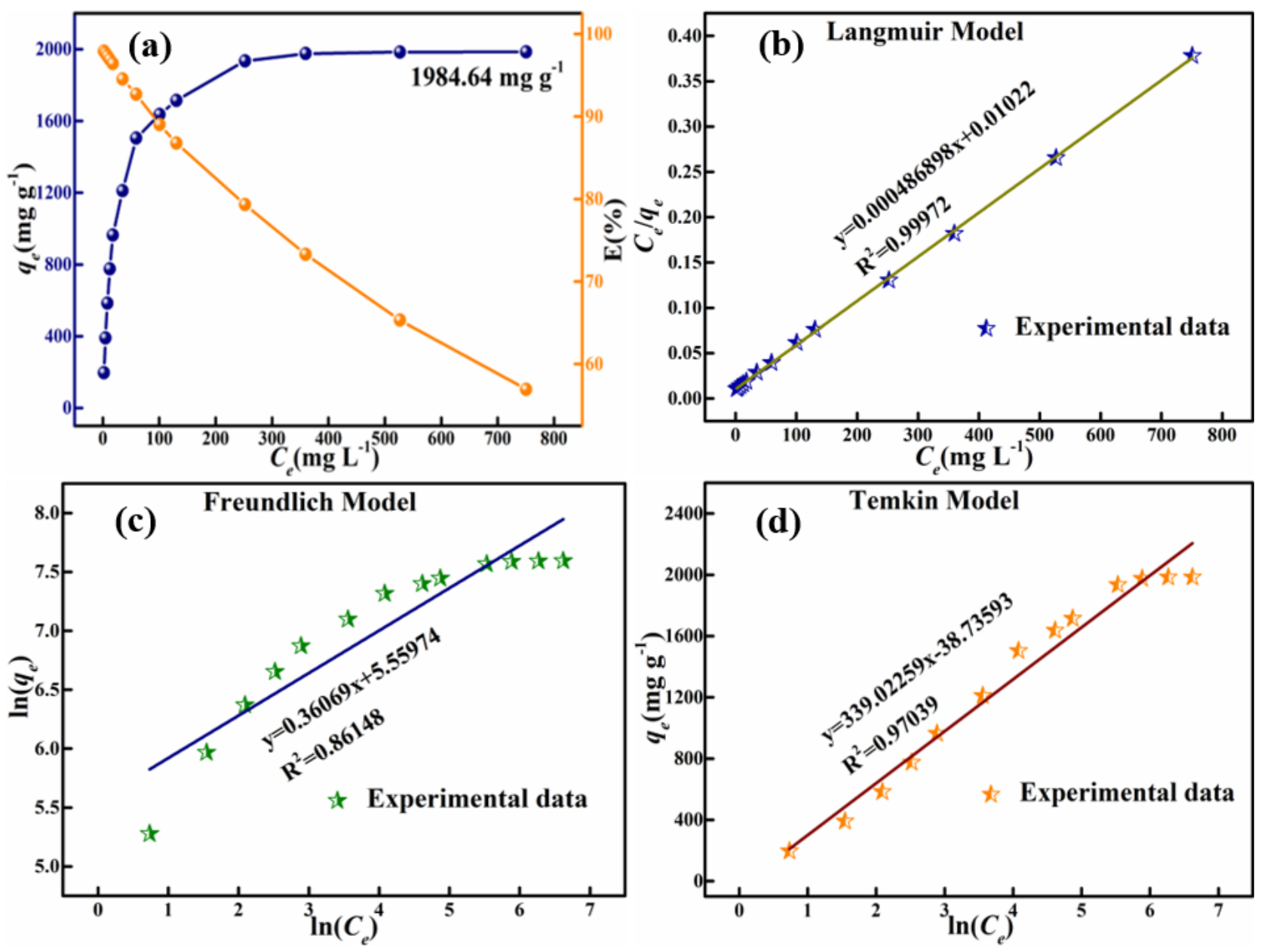

Figure 10. (a) Adsorption isotherms and percentage removal of $C R$ as a function of the initial concentration; plots fitted with (b) Langmuir Model, (c) Freundlich Model and (d) Temkin Model for adsorption of $\mathrm{CR}$ on samples $\mathrm{HPMA}\left(\mathrm{T}=25^{\circ} \mathrm{C}\right.$, adsorbent mass $=100 \mathrm{mg}$ and $\left.\mathrm{pH}=4\right)$.

To investigate the effect of different $\mathrm{pH}$ on the saturation adsorption capacity, adsorption was carried out in solutions of $\mathrm{pH} 2,4,6,8,10$ and 12 (Congo Red mass concentration of $250 \mathrm{mg} \mathrm{L}$, adsorbent mass of $100 \mathrm{mg}$, temperature of $25^{\circ} \mathrm{C}$ ). The variation of adsorption and removal rates of Congo Red, with $\mathrm{pH}$ values of the solution increasing from 2 to 12, are shown in Figure 11. It can be seen that the equilibrium adsorption capacities of the as-synthesized HPMA nanoparticle ranged from $491.86 \mathrm{mg} \mathrm{g}^{-1}$ to $492.19 \mathrm{mg} \mathrm{g}^{-1}$ at $\mathrm{pH}$ values from 2 to 4 . The saturation adsorption of Congo Red gradually decreased from $492.19 \mathrm{mg} \mathrm{g}^{-1}$ ( $\mathrm{pH}$ value of 4 ) to $103.67 \mathrm{mg} \mathrm{g}^{-1}$ ( $\mathrm{pH}$ value of 12) as the $\mathrm{pH}$ of the solution exceeded 4 (from $\mathrm{pH}$ value of 6 to of 12 ), and removal efficiency reduced from $98.44 \%(\mathrm{pH}$ value of 4 ) to $20.73 \%$ ( $\mathrm{pH}$ value of 12 ). The $\mathrm{pH}$ effects on adsorption capacity for Congo Red could be explained by the charge attraction; in the acid solution, the pyridines rings on the HPMA surface were promoted and attracted anionic dye, Congo Red. As the hydroxide ions in the solution increased with increasing $\mathrm{pH}$, and as Congo Red ions and hydroxide ions carry the same electrical charge, the hydroxide ions also occupied adsorption sites on the surface of the material, which increased the competition between the hydroxide ions and the Congo Red ions [28,37,38,42], therefore, the adsorption capacity of Congo Red on the high-porosity HPMA material in the acid solution Was better than that in the base solution. 


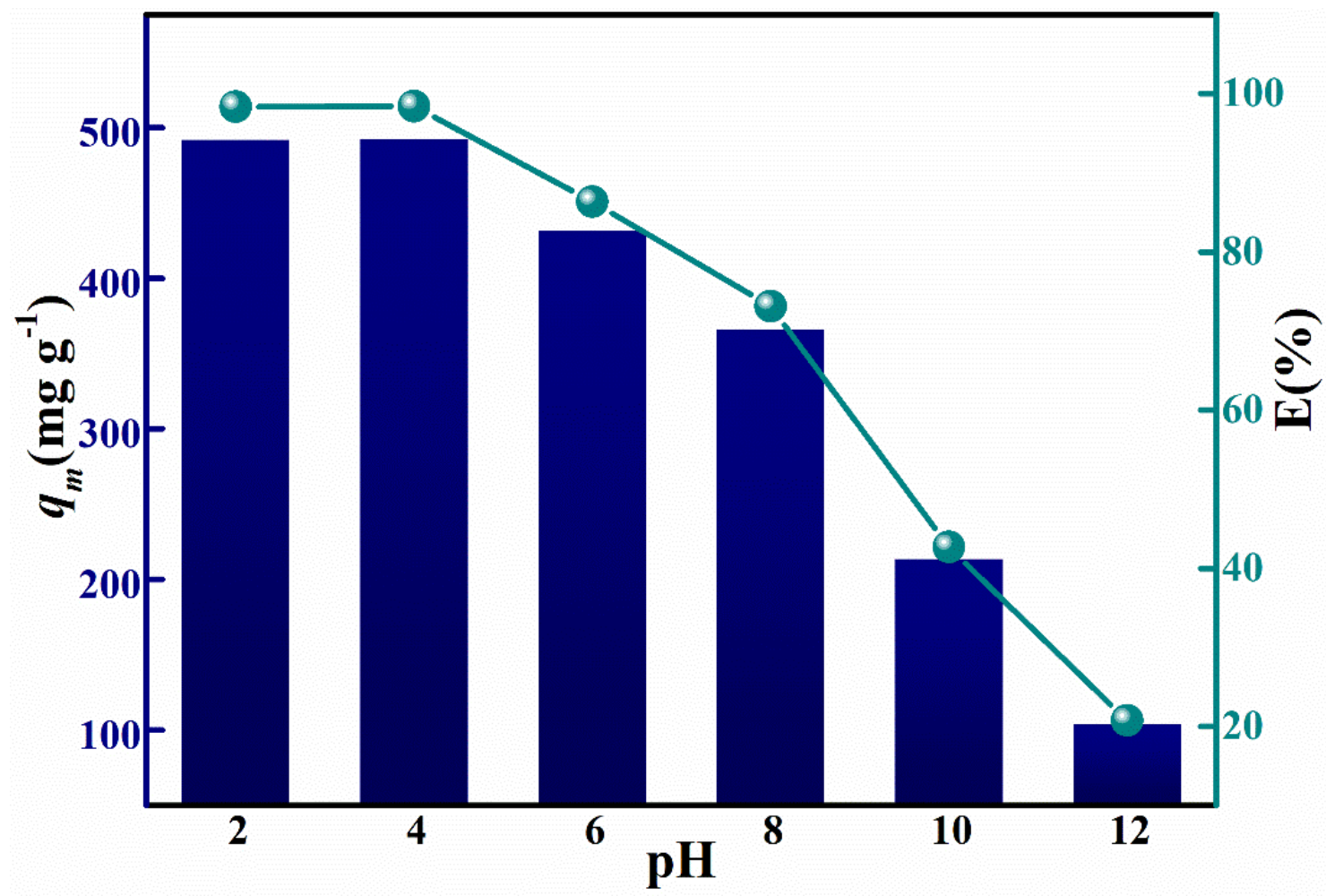

Figure 11. $\mathrm{pH}$ effect on the equilibrium adsorption capacity and removal efficiencies of CR in HPMA samples.

In order to evaluate the adsorption capacity of the HPMA adsorbents for the removal of CR dyes, and its adsorption maxima for Congo Red were compared with other as-reported metal hydroxides. Moreover, the comparison of the maximum monolayer adsorption $\left(q_{\mathrm{m}}\right)$ for CR removal by various series of adsorbents is shown in Table 13, Further observation indicates that the maximum adsorption capacity of the as-prepared high-porosity HPMA nanoparticles for CR was significantly higher than that of the majority of reported materials. For instance, the adsorption capacity of the magnetic core-manganese oxide shell for CR was just $43.00 \mathrm{mg} \mathrm{g}^{-1}$, while the adsorption capacity of the as-synthesized alumina powder, with a high-porosity structure, for CR was $1984.64 \mathrm{mg} \mathrm{g}^{-1}$, about 46.15 times higher than that of the magnetic core-manganese oxide shell. The high adsorption capacity is due to the higher specific area and novel high-porosity nanostructures. It indicates that the HPMA material prepared in this study has excellent adsorption properties for Congo Red, and, thus, has the potential for wide application in the treatment of industrial dyes containing Congo Red.

Table 13. Comparison of the maximum monolayer adsorption $\left(q_{m}\right)$ of different adsorbents for the removal of $\mathrm{CR}$.

\begin{tabular}{|c|c|c|}
\hline \multirow{2}{*}{ Adsorbents } & $q_{m}\left(\mathrm{mg} \mathrm{g}^{-1}\right)$ & \multirow{2}{*}{ References } \\
\hline & CR & \\
\hline HPMA nanopowder & 1984.64 & This study \\
\hline $\mathrm{a}-\mathrm{Fe}_{2} \mathrm{O}_{3}$ nanoparticles and nanowhiskers & 254.00 & [68] \\
\hline HAM@ $\gamma-\mathrm{AlOOH} / \mathrm{Fe}(\mathrm{OH})_{3}$ & 252.53 & [69] \\
\hline $\mathrm{Fe}_{3} \mathrm{O}_{4} @ \mathrm{P} 4-\mathrm{VP}$ nanospheres & 151.50 & {$[70]$} \\
\hline spindle-like $\gamma-\mathrm{Al}_{2} \mathrm{O}_{3}$ & 176.70 & [71] \\
\hline$\alpha-F e O O H$ nanorods & 104.2 & [72] \\
\hline nanorod-like mesoporous $\gamma-\mathrm{Al}_{2} \mathrm{O}_{3}$ & 83.80 & [73] \\
\hline magnetic core-manganes oxide shell & 43.00 & [74] \\
\hline $\mathrm{Fe}_{2} \mathrm{O}_{3} @ \mathrm{mSiO}_{2}$ & 72.22 & [65] \\
\hline
\end{tabular}




\section{Conclusions}

In summary, we have synthesized HPMA with a porous structure using non-toxic, cheap sodium hydroxide and industrial aluminum hydroxide by a simple direct ageing method and ammonium salt substitution. The results show that HPMA materials have excellent thermal stability at the purity of $99.9661 \%$ and total impurities removal rates of $98.87 \%$, and shows the advantages of both their microstructures and nanostructures, which avoid the aggregation of HPMA nanoparticles and maintain high specific surface areas, a high value of pore volume and ideal pore size distribution, enhancing the surface energy and surface bonding energy, which can be easily stabilized by bonding with other atoms to enhance the chemical activity of HPMA. The greater chemical activity induces corresponding changes in atomic transport and conformation on the surface of the alumina nanoparticles, leading to changes in the electron spin conformation and electronic energy spectrum on the surface of the HPMA material particles, contributing to the improved adsorption performance of HPMA. Moreover, the adsorption mechanism of CR in solution is electrostatic adsorption and the zeta potential of HPMA is $46 \pm 3 \mathrm{mV}$, with potential values between $40-60 \mathrm{mV}$, indicating that the adsorbent has a positive surface charge and outstanding surface stability, conferring good adsorption performance the HPMA particle for CR. The maximum capacities of the HPMA nanostructures with high porosity for CR have been determined to be $1984.64 \mathrm{mg} \mathrm{g}^{-1}$, demonstrating its promising potential in environmental remediation. The underlying adsorption kinetics follow the pseudo-secondorder model, and the adsorption isotherms follow the Langmuir model. The synthesis method is simple, versatile and controllable, which makes it possible to easily achieve efficient HPMA production at the gram level for the treatment of toxic dyes in wastewater. Owing to their highly porous structures, special surface properties and high surface areas, HPMA nanoparticles are potentially applicable in water purification.

Author Contributions: Z.L. and D.W. contributed equally to this work. Conceptualization, Z.L. and Y.L. (Yibing Li); methodology, Z.L. and D.W.; software, Z.L.; validation, D.W., J.C., C.W., Y.L. (Yuping Li) and F.L.; formal analysis, Z.L.; investigation, Z.L.; resources, Y.L. (Yibing Li); data curation, Z.L.; writing-original draft preparation, Z.L. and D.W.; writing-review and editing, J.S.; visualization, Y.L. (Yibing Li); supervision, Y.L. (Yibing Li); project administration, Y.L. (Yibing Li). All authors have read and agreed to the published version of the manuscript.

Funding: This research received no external funding.

Institutional Review Board Statement: Not applicable.

Informed Consent Statement: Not applicable.

Data Availability Statement: The data used to support the findings of this study are available from the corresponding author upon request.

Acknowledgments: The authors are grateful for the Key Laboratory of New Processing Technology for Nonferrous Metals and Materials, Ministry of Education, Guilin University of Technology.

Conflicts of Interest: The authors declare no conflict of interest.

\section{References}

1. Jones, M.; Hutchings, G.J.; Willock, D.J.; Scott, J.; Taylor, S.H. Zinc promoted alumina catalysts for the fluorination of chlorofluorocarbons. J. Catal. 2018, 364, 102-111. [CrossRef]

2. Wang, F.; Chen, P.; Li, X.; Zhu, B.Q. Effect of micro-spinel powders addition on the microstructure and properties of alumina refractory castables. Ceram. Int. 2019, 45, 2989-2999. [CrossRef]

3. Zhang, D.; Zhou, S.; Liu, Y.; Fan, X.; Zhang, M.L.; Zhai, J.; Jiang, L. Self-Assembled porphyrin nanofiber membrane-decorated alumina channels for enhanced photoelectric response. ACS Nano 2018, 12, 11169-11177. [CrossRef] [PubMed]

4. Zheng, Y.; Zhang, K.; Liu, T.T.; Liao, W.H.; Zhang, C.D.; Shao, H. Cracks of alumina ceramics by selective laser melting. Ceram. Int. 2019, 45, 175-184. [CrossRef]

5. Kumari, U.; Behera, S.K.; Meikap, B.C. A novel acid modified alumina adsorbent with enhanced defluoridation property: Kinetics, isotherm study and applicability on industrial wastewater. J. Hazard. Mater. 2019, 365, 868-882. [CrossRef] 
6. Nguyen, T.D.; Tang, D.; D’Acierno, F.; Michal, C.A.; MacLachlan, M.J. Biotemplated light weight $\gamma$-Alumina aerogels. Chem. Mater. 2018, 30, 1602-1609. [CrossRef]

7. Chen, X.; Zheng, X.; Lin, W.; Michal, C.A.; MacLachlan, M.J. Adsorption property and catalytic performance over ordered mesoporous phosphorus-doped Pd-alumina catalysts. Powder Technol. 2018, 338, 869-877. [CrossRef]

8. Busca, G. The surface of transitional aluminas: A critical review. Catal. Today 2014, 226, 2-13. [CrossRef]

9. Maruoka, H.; Tomita, A.; Zheng, L.; Kimura, T. Mesopore connectivity improving aerosol-assisted synthesis of mesoporous alumina powders with high surface area. Langmuir 2018, 34, 13781-13787. [CrossRef]

10. Liu, S.; Liang, X.; Zhang, J.; Chen, B. Temperature sensitive synthesis of $\gamma-\mathrm{Al}_{2} \mathrm{O}_{3}$ support with different morphologies for $\mathrm{CoMo} / \gamma-\mathrm{Al}_{2} \mathrm{O}_{3}$ catalysts for hydrodesulfurization of thiophene and 4,6-dimethyldibenzothiophene. Catal. Sci. Technol. 2017, 7, 466-480. [CrossRef]

11. Wang, X.H.; Ni, H.H.; Cao, Y.; Li, G.; Gao, H.; Yang, J.L. The Reaction Kinetics of Aluminum and Isopropanol. Appl. Mech. Mater 2012, 164, 21-25. [CrossRef]

12. Smith, P.; Power, G. High purity alumina-current and future production. Miner. Processing Extr. Metall. Rev. 2021. [CrossRef]

13. Lee, G.; Chen, C.; Yang, S.T.; Ahn, W.S. Enhanced adsorptive removal of fluoride using mesoporous alumina. Microporous Mesoporous Mater. 2010, 127, 152-156. [CrossRef]

14. Nalivaiko, A.Y.; Ozherelkov, D.Y.; Pak, V.I.; Kirov, S.S.; Arnautov, A.N.; Gromov, A.A. Preparation of aluminum hydroxide during the synthesis of high purity alumina via aluminum anodic oxidation. Metall. Mater. Trans. B-Prcocess Metall. Mater. Processing Sci. 2020, 51, 1154-1161. [CrossRef]

15. Kim, S.W.; Jung, Y.M. Nanocrystalline particle coatings on a-alumina powders by a carbonate precipitation and thermal-assisted combustion route. J. Nanosci. Nanotechnol. 2007, 11, 3906-3909. [CrossRef] [PubMed]

16. Yong-Taeg, O.; Kim, S.W.; Shin, D.C. Fabrication and synthesis of alpha-alumina nanopowders by thermal decomposition of ammonium aluminum carbonate hydroxide (AACH). Colloids Surf. A Physicochem. Eng. Asp. 2008, 313, 415-418.

17. Ambaryan, G.N.; Vlaskin, M.S.; Buryakovskaya, O.A.; Kislenko, S.; Zhuk, A.; Shkolnikov, E.; Arnautov, A.; Zmanovsky, S.; Osipenkova, A.; Tarasov, V.; et al. Advanced manufacturing process of ultrahigh-purity $\alpha-\mathrm{Al}_{2} \mathrm{O}_{3}$. Sustain. Mater. Technol. 2018, 17, e00065. [CrossRef]

18. Bae, H.C.; Lee, S.J. Study on the fabrication processing of high-purity, high-density alumina green body prepared by a hydrothermal method. J. Ceram. Processing Res. 2015, 16, 319-323.

19. Suchanek, W.L. Hydrothermal Synthesis of Alpha Alumina (alpha- $\mathrm{Al}_{2} \mathrm{O}_{3}$ ) Powders: Study of the Processing Variables and Growth Mechanisms. J. Am. Ceram. Soc. 2010, 93, 399-412. [CrossRef]

20. Popp, U.; Herbig, R.; Michel, G.; Muller, E.; Oeatreich, C. Properties of nanocrystalline ceramic powders prepared by laser evaporation and recondensation. J. Eur. Ceram. Soc. 1998, 18, 1153-1160. [CrossRef]

21. Gautam, R.; Mudhoo, A.; Chattopadhyaya, M. Kinetic, equilibrium, thermodynamic tudies and spectroscopic analysis of Alizarin Red S removal by adsorption onto ustard husk. J. Environ. Chem. Eng. 2013, 1, 1283-1291. [CrossRef]

22. Roosta, M.; Ghaedi, M.; Daneshfar, A.; Sahraei, R. Experimental design-based response surface methodology optimization of ultrasonic assisted adsorption of safaranin $\mathrm{O}$ by tin sulfide nanoparticle loaded on activated carbon. Spectrochim. Acta 2014, 122, 223-231. [CrossRef] [PubMed]

23. Chatterjee, S.; Lee, M.; Woo, S. Adsorption of congo red by chitosan hydrogel beads impregnated with carbon nanotubes. Bioresour. Technol. 2010, 101, 1800-1806. [CrossRef] [PubMed]

24. Soylak, M.; Yilmaz, E.; Ghaedi, M.; Montazerozohori, M. Cloud point extraction and flame atomic absorption spectrometry determination of lead (II) in environmental and food samples. J. AOAC Int. 2012, 95, 1797-1802. [CrossRef]

25. Espergham, O.; Ghaedi, M.; Niknam, K.; Kokhdan, S.N. A cloud point extraction methodology for the determination of trace amounts of copper, cobalt, zinc and manganese by flame atomic absorption spectrometry using a new imidazole derivative. Fresenius Environ. Bullet. 2011, 20, 2350-2356.

26. Ghaedi, M.; Niknam, K.; Niknam, E.; Soylak, M. Application of cloud point extraction for copper, nickel, zinc and iron ions in environmental samples. J. Chin. Chem. Soc. 2013, 56, 981-986. [CrossRef]

27. Ghaedi, M.; Shokrollahi, A.; Niknam, K.; Niknam, E.; Najibi, A.; Soylak, M. Cloud point extraction and flame atomic absorption spectrometric determination of cadmium (II), lead (II), palladium (II) and silver(I) in environmental samples. J. Hazard. Mater. 2009, 168, 1022-1027. [CrossRef]

28. Chafi, M.; Gourich, B.; Essadki, A.; Vial, L.; Fabregat, A. Comparison of electrocoagulation using iron and aluminium electrodes with chemical coagulation for the removal of a highly soluble acid dye. Desalination 2011, 281, 285-292. [CrossRef]

29. Vijayaraghavan, G.; Shanthakumar, S. Performance study on algal alginate as natural coagulant for the removal of Congo red dye Desal. Water Treat. 2016, 57, 6384-6392. [CrossRef]

30. Munagapati, V.; Kim, D. Equilibrium isotherms, kinetics, and thermodynamics studies for Congo Red adsorption using calcium alginate beads impregnated with nano-goethite. Ecotox. Environ. Saf. 2017, 141, 226-234. [CrossRef]

31. Omran, A.; Baiee, M.; Juda, S. Removal of Congo red dye from aqueous solution using a new adsorbent surface developed from aquatic plant (Phragmites australis). Int. J. ChemTech Res. 2016, 9, 334-342.

32. Satheesh, R.; Vignesh, K.; Rajarajan, M.; Suganthi, A.; Sreekantan, S.; Knag, M.; Kwak, B.S. Removal of Congo red from water using quercetin modified $\alpha-\mathrm{Fe}_{2} \mathrm{O}_{3}$ nanoparticles as effective nanoadsorbent. Mater. Chem. Phys. 2016, 180, 53-65. [CrossRef]

33. Solísabbba, M. Microbial decolouration of azo dyes: A review. Process Biochem. 2012, 47, 1723-1748. 
34. Liu, M.; Chen, Q.; Lu, K.; Huang, W.; Lu, Z.; Zhou, C.; Yu, S.; Gao, C. High efficient removal of dyes from aqueous solution through nanofiltration using diethanolamine-modified polyamide thin-film composite membrane. Sep. Pur. Technol. 2017, 173, 135-143. [CrossRef]

35. Zhou, J.; Tang, C.; Cheng, B.; Yu, J.; Jaroniec, M. Rattle-type carbon-alumina core-shell spheres: Synthesis and application for adsorption of organic dyes. ACS Appl. Mater. Inter. 2012, 4, 2174-2179. [CrossRef]

36. Roy, T.; Mondal, N. Biosorption of Congo Red from aqueous solution onto burned root of Eichhornia crassipes biomass. Appl. Water Sci. 2017, 7, 1841-1854. [CrossRef]

37. Carmen, A.; Ghinea, C.; Alves, M.; Gavrilescu, M. Removal of Erythrosine B dye from water effluents using crop waste pumpkin seed hulls as adsorbent. Desal. Water Treat. 2016, 57, 22585-22608. [CrossRef]

38. Fang, B.; Bao, Z.; Lu, L.; Zhao, L.; Wang, H. Preparation of a hierarchical flower-like $\gamma-\mathrm{Al}_{2} \mathrm{O}_{3} @ \mathrm{C}$ composite exhibiting enhanced adsorption performance for congo red by high temperature transformation of $\gamma$-AlOOH@ $\mathrm{C}$ precursors. RSC Adv. 2016, 6, 61-64. [CrossRef]

39. Liu, S.; Cai, Y.; Cai, X.; Li, H.; Zhang, F.; Mu, Q.; Wang, Y.; Wang, D. Catalytic photodegradation of Congo red in aqueous solution by $\mathrm{Ln}(\mathrm{OH})_{3},(\mathrm{Ln}=\mathrm{Nd}, \mathrm{Sm}, \mathrm{Eu}, \mathrm{Gd}, \mathrm{Tb}$, and Dy) nanorods. Appl. Catal. A 2013, 453, 45-53. [CrossRef]

40. Ong, C.; Mohammad, A.; Rohani, R.; Ba-Abbad, M.M. Solar photocatalytic degradation of hazardous Congo red using lowtemperature synthesis of zinc oxide nanoparticles. Process Saf. Environ. 2016, 104, 549-557. [CrossRef]

41. Thomas, M.; Naikoo, G.; Sheikh, M.; Bano, M.; Khan, F. Effective photocatalytic degradation of Congo red dye using alginate/carboxymethyl cellulose $/ \mathrm{TiO}_{2}$ nanocomposite hydrogel under direct sunlight irradiation. J. Photochem. Photobio. A 2016, 327, 33-43. [CrossRef]

42. Tanwar, R.; Kumar, S.; Mandal, U. Photocatalytic activity of PANI/Fe0 doped BiOCl under visible light-degradation of Congo red dye. J. Photochem. Photobio. A 2017, 333, 105-116. [CrossRef]

43. Rengaraj, S.; Moona, S.; Sivabalan, R.; Arabindoo, B.; Murugesan, V. Removal of phenol from aqueous solution and resin manufacturing industry wastewater using an agricultural waste: Rubber seed coat. J. Hazard. Mater. 2002, 89, 185-196. [CrossRef]

44. Malik, P. Dye removal from wastewater using activated carbon developed from sawdust: Adsorption equilibrium and kinetics. J. Hazard. Mater. 2004, 113, 81-88. [CrossRef] [PubMed]

45. Guo, Y.; Zhao, J.; Zhang, H.; Yang, S.; Qi, J.; Wang, Z.; Xu, H. Use of rice husk-based porous carbon for adsorption of rhodamine B from aqueous solutions. Dye. Pigm. 2005, 66, 123-128. [CrossRef]

46. Rehman, M.; Kim, I.; Han, J. Adsorption of methylene blue dye from aqueous solution by sugar extracted spent rice biomass Carbohyd. Polym. 2012, 90, 1314-1322. [CrossRef]

47. Dubey, S.; Singh, A.; Nim, B.; Singh, I.B. Optimization of molar concentration of $\mathrm{AlCl}_{3}$ salt in the sol-gel synthesis of nanoparticles of gamma alumina and their application in the removal of fluoride of water. J. CFCSol-Gel Sci. Techn. 2017, 82, 468-477. [CrossRef]

48. Xu, N.; Liu, Z.; Dong, Y.; Hong, T.; Dang, L.; Li, W. Controllable synthesis of mesoporous alumina with large surface area for high and fast fluoride removal. Ceram. Int. 2016, 42, 15253-15260. [CrossRef]

49. Zhu, W.; He, D.; Han, C.; He, S.; Liao, M.; Shan, X.; Luo, Y. Optimization of As (V) removal from contaminated water with mesoporous alumina: Effects of $\mathrm{pH}$, contact time, concentration and temperature. J. Environ. Eng. 2017, 143, 9. [CrossRef]

50. Lanas, S.; Valiente, M.; Aneggi, E.; Trovarelli, A.; Tolazzi, M.; Melchior, A. Efficient fluoride adsorption by mesoporous hierarchical alumina microspheres. RSC Adv. 2016, 6, 42288-42296. [CrossRef]

51. Xu, N.; Liu, Z.; Bian, S.; Dong, Y.; Li, W. Preparation of $\mathrm{MnO}_{2}-\mathrm{Al}_{2} \mathrm{O}_{3}$ adsorbent with large specific surface area for fluoride removal. Particuology 2016, 27, 66-71. [CrossRef]

52. Padmaja, P.; Pillai, P.K.; Warrier, K.G.K.; Padmanabhan, M. Adsorption isotherm and pore characteristics of nano alumina derived from sol-gel boehmite. J. Porous Mater. 2004, 11, 147-155. [CrossRef]

53. Wu, Y.S.; Ma, J.; Hu, F.; Li, M.C. Synthesis and Characterization of Mesoporous Alumina via a Reverse Precipitation Method. J. Mater. Sci. Technol. 2012, 28, 572-576. [CrossRef]

54. Jian-hong, Y.; You-yi, S.; Jian-feng, G.; Chun-yan, X. Synthesis of crystalline $\gamma-\mathrm{Al}_{2} \mathrm{O}_{3}$ with high purity. Trans. Nonferrous Met. Soc. China 2009, 19, 1237-1242.

55. Zaitan, H.; Bianchi, D.; Achak, O.; Chafik, T.A. comparative study of the adsorption and desorption of o-xylene onto bentonite clay and alumina. J. Hazard. Mater. 2008, 153, 852-859. [CrossRef]

56. Cai, W.Q.; Li, H.Q.; Zhang, Y. Azeotropic distillation-assisted preparation of macro-mesostructured $\gamma-\mathrm{Al}_{2} \mathrm{O}_{3}$ nanofibres of crumpled sheet-like morphology. Mater. Chem. Phys. 2006, 96, 136-139. [CrossRef]

57. Chanda, S.C.; Manna, A.; Vijavan, V.; Nayak, P.; Ashok, M.; Acharya, H.N. PIXE \& XRD analysis of nanocrystals of Fe, Ni and $\mathrm{Fe}_{2} \mathrm{O}_{3}$. Mater. Lett. 2007, 61, 5059-5062.

58. Li, D.; Schubert, B.; Norman, J.W. Characterization of gationic polyelectrolytes adsorption to an anionic emulsion via zeta-potential and microcalorimetry. J. Surfactants Deterg. 2014, 4, 655-667. [CrossRef]

59. Alyassin, Y.; Sayed, E.G.; Mehta, P.; Ruparelia, K.; Arshad, M.S.; Rasekh, M.; Shepherd, J.; Kucuk, L.; Wilson, P.B.; Singh, N. Application of mesoporous silica nanoparticles as drug delivery carriers for chemotherapeutic agents. Drug Discov. Today 2020, 25, 1513-1520. [CrossRef]

60. Nicola, R.; Muntean, S.G.; Nistor, M.A.; Putz, A.M.; Almasy, L.; Sacarescu, L. Highly efficient and fast removal of colored pollutants from single and binary systems, using magnetic mesoporous silica. Chemosphere 2020, 261, 127737. [CrossRef] 
61. Zhang, Y.; Bai, L.; Zhou, W.; Lu, R.; Gao, H.; Zhang, S. Superior adsorption capacity of $\mathrm{Fe}_{3} \mathrm{O}_{4} @ \mathrm{nSiO}_{2} @ \mathrm{mSiO}_{2}$ core-shell microspheres for removal of Congo red from aqueous solution. J. Mol. Liq. 2016, 219, 88-94. [CrossRef]

62. Weber, W.; Morris, J. Kinetics of adsorption on carbon from solution. J. Sanit. Eng. Div. 1963, 89, 31-60. [CrossRef]

63. Pal, S.; Patra, A.; Ghorai, S.; Sarkar, A.; Mahato, V.; Sarkar, S.; Singh, R. Efficient and rapid adsorption characteristics of templating modified guar gum and silica nanocomposite toward removal of toxic reactive blue and Congo red dyes. Bioresour. Technol. 2015, 191, 291-299. [CrossRef] [PubMed]

64. Kumar, P.S.; Kirthika, K. Equilibrium and kinetic study of adsorption of nickel from aqueous solution onto Bael tree leaf powder. J. Eng. Sci. Technol. 2009, 4, 351-363.

65. Assche, T.R.; Baron, G.V.; Denayer, J.F. An explicit multicomponent adsorption isotherm model: Accounting for the size-effect for components with Langmuir adsorption behavior. Adsorption 2018, 24, 517-530. [CrossRef]

66. Darvishi, R.; Soltani, C.; Hassani, A.; Karaca, S.; Khataee, A. Preparation of cetyltrimethylammonium bromide modified montmorillonite nanomaterial for adsorption of a textile dye. J. Taiwan Inst. Chem. Eng. 2014, 45, 2565-2577.

67. Samad, A.; Din, M.I.; Ahmed, M.; Ahmad, S. Synthesis of zinc oxide nanoparticles reinforced clay and their applications for removal of $\mathrm{Pb}$ (II) ions from aqueous media. Chin. J. Chem. Eng. 2021, 32, 454-461. [CrossRef]

68. Hao, T.; Yang, C.; Rao, X.; Wang, J.; Niu, C.; Su, X. Facile additive-free synthesis of iron oxide nanoparticles for efficient adsorptive removal of Congo red and Cr(VI). Appl. Surf. Sci. 2014, 292, 174-180. [CrossRef]

69. Zhang, Y.; Ye, Y.; Zhou, X.; Liu, Z.; Zhu, G.; Li, D.; Li, X. Monodispersed hollow aluminosilica microsphere@hierarchical $\gamma$-AlOOH deposited with or without $\mathrm{Fe}(\mathrm{OH})_{3}$ nanoparticles for efficient adsorption of organic pollutants. J. Mater. Chem. A 2016, 4, 838-846. [CrossRef]

70. Zeng, B.; Yang, L.; Zheng, W.; Zhu, J.; Ma, X.; Liu, X.; Yuan, C.; Xu, Y.; Dai, L. Analysis of the formation process and performance of magnetic $\mathrm{Fe}_{3} \mathrm{O}_{4} @ P o l y(4-v i n y l p y r i d i n e)$ absorbent prepared by in-situ synthesis. J. Mater. Sci. Technol. 2018, 34, $999-1007$. [CrossRef]

71. Cai, W.; Yu, J.; Jaroniec, M. Template-free synthesis of hierarchical spindle-like $\gamma-\mathrm{Al}_{2} \mathrm{O}_{3}$ materials and their adsorption affinity towards organic and inorganic pollutants in water. J. Mater. Chem. 2010, 20, 4587-4594. [CrossRef]

72. Zhang, E.L.; Sun, X.J.; Liu, X.T.; Wang, Q.D. Morphology controlled synthesis of $\alpha$-FeOOH crystals and their shape-dependent adsorption for decontamination of Congo red dye. Mater. Res. Innov. 2015, 19, 385-391. [CrossRef]

73. Cai, W.; Hu, Y.; Chen, J.; Zhang, G.; Xia, T. Synthesis of nanorod-like mesoporous $\gamma-\mathrm{Al}_{2} \mathrm{O}_{3}$ with enhanced affinity towards Congo red removal: Effects of anions and structure-directing agents. Crystengcomm 2012, 14, 972-977. [CrossRef]

74. Zhai, Y.; Zhai, J.; Zhou, M.; Dong, S. Ordered magnetic core-manganese oxide shell nanostructures and their application in water treatment. J. Mater. Chem. 2009, 19, 7030-7035. [CrossRef] 